\title{
Low Cost Carriers in the Middle East and North Africa: Prospects and Strategies
}

\author{
William G. Morrison ${ }^{1}$ and Keith Mason ${ }^{2}$
}

September 2016

\begin{abstract}
We examine socio-economic indicators relevant to 'low cost carriers' (LCCs) in the Middle East and North Africa (MENA) and review the evolution of air transport liberalization and air service agreements in the region. We analyse the business strategies of MENA-based LCCs and using a benchmarking methodology, we compare the business strategy of Air Arabia Group with those of dominant European LCCs easyJet and Ryanair. Our economic development indicators suggest future potential for LCC growth in Iran and Saudi Arabia while other MENA countries continue to face challenges. The lack of success in regional liberalization in air transport is restricting LCC growth although individual MENA countries have or will benefit from 'open skies' agreements. MENA-based LCCs while retaining some characteristics of the LCC model also deviate in significant ways. Benchmarking analysis shows that Air Arabia's business strategy represents a departure from the business strategies that have been most successful in Europe.
\end{abstract}

Keywords: Low cost carriers, MENA.

\section{$\underline{\text { Acknowledgements }}$}

We would like to thank Nadine Itani for her contribution to an earlier presentation that paved the way for this article and for her helpful comments on this manuscript.

\footnotetext{
${ }^{1}$ Associate Professor, Lazaridis School of Business and Economics, Wilfrid Laurier University, Waterloo, Canada; corresponding author: wmorrison@wlu.ca

${ }^{2}$ Reader, Centre for Air Transport Management, Cranfield University, UK.
} 


\section{Introduction}

This paper explores the current environment, prospects and strategies of so-called 'low cost airlines' (LCCs) in the Middle East and North Africa (MENA) region. ${ }^{3}$ Specifically, we examine economic development indicators to determine the general environment facing LCCs, we review the evolution of air transport liberalisation and air service agreements and we compare the business strategies of MENA-based airlines in the low cost sector with those of successful European LCCs.

The MENA region has recorded impressive growth in air passenger traffic in recent years. Much of this growth has been fuelled by the emergence of Middle Eastern carriers focused on international long haul flights. Between 2009 and 2013, passenger traffic between MENA countries and the Americas, Asia Pacific and Europe regions grew 18\%, 33\% and 22\% respectively and over the same period passenger traffic within the MENA region also increased $22 \% .^{4}$ While such growth is impressive, the MENA LCC sector currently accounts for a much smaller market share compared with LCCs elsewhere in the world. In 2014, LCCs accounted for $15 \%$ of available seat kilometers within the Middle East and 7\% to/from the Middle East. Similarly, within Africa LCCs account for around $10 \%$ of total seat capacity. ${ }^{5}$ These market shares are significantly lower than those for LCCs in Europe, North America and Southeast Asia. Why have LCCs in the MENA region not been more successful relative to their counterparts around the world? One potential reason is that the region is at stage in its economic development in which inhibits faster growth for LCCs. One might also consider whether a lack of trade liberalization in air services has created a more restrictive environment for the low cost sector in MENA countries. Thirdly, it is possible that MENA-based LCCs differ in their business strategies in ways that result in lower market shares. We investigate all of these potential explanations.

We begin with an economic overview of MENA countries that attempts to identify possible indicators of demand for air transport and for LCCs in particular. In section 3, we review the recent history and current state of intra-regional and inter-regional air transport

\footnotetext{
${ }^{3}$ MENA encompasses Algeria, Egypt, Iran, Iraq, Israel, Jordan, Kuwait, Lebanon, Libya, Morocco, Oman, the Palestinian territories, Qatar, Saudi Arabia (KSA), Syria, Tunisia, Yemen and United Arab Emirates (UAE). ${ }^{4}$ See Amadeus (2014)

${ }^{5}$ OAG (2012), CAPA (2013). Note that the LCC shares of capacity for within the African continent overstates the current role of LCCs in Northern countries as much of the LCC presence is in South Africa.
} 
liberalization agreements and in section 4 we examine the characteristics and evolution of MENA-based 'LCCs' and utilize a benchmarking methodology to compare the business strategy of Air Arabia Group with those of established European LCCs easyJet and Ryanair. We offer some concluding remarks in section 5 .

\section{Economic Indicators of LCC Sector Growth}

Data availability for MENA countries is a challenge, however we have assessed the current environment and potential for growth in air transport (and LCCs in particular) using five indicators;

1. Macroeconomic (GDP) growth - a general indicator for air travel demand.

2. Median income per capita - a proxy for the size of the middle income class.

3. Urban development and geography - measuring the extent to which there are cities within a country that can support domestic LCC travel.

4. Internet penetration - a measure of the ability of airlines to sell directly to their customers via online distribution and sales.

5. The trend in foreign visitor spending - a proxy for the extent to which a country is becoming a destination for inbound air passengers.

In general, growth in air transport is correlated with macroeconomic growth and associated macroeconomic shocks. ${ }^{6}$ Table 1 shows the size of MENA economies and macroeconomic growth over the last five years along with GDP per capita. In 2014, 75\% of MENA economic output was accounted for by oil exporting countries and $22 \%$ by Saudia Arabia alone. With the exception of Iran, Kuwait and Libya, the oil exporting MENA countries have recorded higher GDP growth rates than the global rate of $2.49 \%$. Among oil importing countries, Jordan and Tunisia also recorded superior rates of macroeconomic growth with Israel and Morocco growing at around the global rate. Per capita GDP varies wildly across MENA countries from $\$ 3,036$ (Egypt) to $\$ 96,732$ (Qatar) however this tells us little about the distribution of income.

An important contributory element in domestic demand for low cost air travel demand is a growing middle class. As Schlumberger and Weisskopf (2014) argue, without a middle income class even low airfares are unaffordable to a large segment of a given domestic population. Measuring the size of a country's middle class is a non-trivial exercise that requires data concerning both the amount and distribution of income. Gini coefficient measures

\footnotetext{
${ }^{6}$ See for example Hansman and Ishutkina (2009).
} 
Table 1: GDP, GDP Growth and Per Capita GDP for the MENA Region by Country

\begin{tabular}{|c|c|c|c|c|c|}
\hline 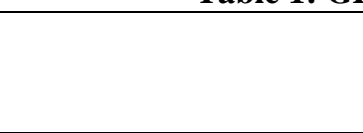 & $\begin{array}{c}\text { Average annual } \\
\text { \% growth }\end{array}$ & $\begin{array}{c}\text { Annual \% } \\
\text { GDP growth }\end{array}$ & $\begin{array}{c}\text { Annual \% } \\
\text { GDP } \\
\text { growth }\end{array}$ & $\begin{array}{c}\text { GDP } \\
\text { (Current \$US) } \\
\text { Millions }\end{array}$ & $\begin{array}{l}\text { GDP per } \\
\text { capita }^{1}\end{array}$ \\
\hline Oil Exporting Nations & 2011-2014 & 2013 & 2014 & 2014 & Current \$US \\
\hline Algeria & 3.18 & 2.80 & 3.80 & 213,518 & 2013 \\
\hline Bahrain & 3.90 & 5.41 & 4.48 & 33,851 & $\$ 5,484$ \\
\hline Iran, Islamic Rep. & -0.11 & -1.91 & 4.34 & 425,326 & $\$ 24,854$ \\
\hline Iraq & 6.48 & 6.57 & -2.12 & 223,508 & $\$ 4,721$ \\
\hline Kuwait & 3.95 & 1.15 & -1.62 & 163,612 & $\$ 6,587$ \\
\hline Libya & 1.21 & -13.55 & -24.00 & 41,143 & $\$ 46,841$ \\
\hline Oman & 3.20 & 3.91 & 2.89 & 81,797 & $\$ 18,815$ \\
\hline Qatar & 6.70 & 4.58 & 3.98 & 210,109 & $\$ 93,552$ \\
\hline Saudi Arabia & 5.37 & 2.67 & 3.47 & 746,249 & $\$ 24,231$ \\
\hline United Arab Emirates & 5.25 & 4.32 & 4.57 & 399,451 & $\$ 44,276$ \\
\hline \multicolumn{6}{|l|}{ Oil Importing Nations } \\
\hline Egypt, Arab Rep. & 2.08 & 2.11 & 2.20 & 286,538 & $\$ 3,036$ \\
\hline Israel & 3.43 & 3.25 & 2.55 & 305,675 & $\$ 35,373$ \\
\hline Jordan & 2.78 & 2.83 & 3.10 & 35,827 & $\$ 5,098$ \\
\hline Lebanon & 1.78 & 0.90 & 2.00 & 45,731 & $\$ 9,754$ \\
\hline Morocco & 3.85 & 4.73 & 2.42 & 110,009 & $\$ 3,060$ \\
\hline Tunisia & 1.94 & 2.89 & 2.70 & 48,613 & $\$ 4,274$ \\
\hline USA & & & & & $\$ 52,980$ \\
\hline Canada & & & & & $\$ 52,305$ \\
\hline
\end{tabular}

Source: World Bank

(which are available for some but not all MENA countries) provide some information about the concentration of income but not the distribution per se. ${ }^{7}$ For example, according to World Bank estimates; Qatar has the same Gini coefficient (41.1) as the USA but these countries do not have the same income distribution or size of middle class.

Table 2 shows Median per-capita GDP measures for MENA countries obtained from onsite surveys carried out by Gallup in each country over several years. This measure of per-capita income is the best available proxy for the size and spending ability of a middle income class and provides a very different picture than that created by per capita GDP. For example, the study finds that median per capita income in Qatar is \$5,117 (expressed in PPP international dollars). Even if this dollar figure is biased downwards, it indicates a very large gap between per capita GDP and the actual incomes of many citizens and residents.

\footnotetext{
${ }^{7}$ The same Gini coefficient value can be obtained from different distribution functions. For example, a Gini coefficient of 50 could be derived from an income distribution in which half of the population have all the income and the other half have nothing or from a distribution in which $20 \%$ of the population are extremely wealthy, $60 \%$ of the population are quite poor and $20 \%$ have nothing.
} 
Table 2: Per Capita GDP and Median Income by Country

\begin{tabular}{|l|c|}
\hline \multicolumn{1}{|c|}{ MENA Countries } & \multicolumn{1}{c|}{$\begin{array}{c}\text { Median per capita income }{ }^{2} \\
\text { PPP International dollars } \\
\text { 2006-2012 }\end{array}$} \\
\hline Algeria & $\$ 1,392$ \\
\hline Bahrain & $\$ 4,778$ \\
\hline Iran, Islamic Rep. & $\$ 3,115$ \\
\hline Iraq & $\$ 617$ \\
\hline Kuwait & $\$ 7,487$ \\
\hline Oman &.. \\
\hline Qatar & $\$ 5,117$ \\
\hline Saudi Arabia & $\$ 4,762$ \\
\hline United Arab Emirates & $\$ 4,041^{*}$ \\
\hline \multicolumn{1}{|c|}{ Oil Importing Nations } & \\
\hline Egypt, Arab Rep. & $\$ 623$ \\
\hline Israel & $\$ 7,847$ \\
\hline Jordan & $\$ 1,559$ \\
\hline Lebanon & $\$ 2,960$ \\
\hline Morocco & $\$ 1,135$ \\
\hline Tunisia & $\$ 1,646$ \\
\hline Developed Countries & \\
\hline USA & $\$ 15,480$ \\
\hline Canada & $\$ 15,181$ \\
\hline
\end{tabular}

Source: Gallup (2013); *Estimate for UAE from Tong (2010).

As a benchmark, the US and Canadian median per capita incomes in the same Gallup study were around $\$ 15,000$. Of MENA countries, Israel has the highest median per capita income at $\$ 7,847$ followed by Kuwait. Incomes in Qatar, KSA and UAE are lower but approaching the income levels of the top three MENA countries. Elsewhere median incomes are very low; in Egypt the Gallup study indicates a median per capita income of $\$ 623$. All of this suggests that a resident middle class is yet to emerge in the region as a source of demand for air travel.

\section{Internet Usage}

The internet has played an important role in the historic development of LCCs because it facilitated a simplified pricing structure and online sales and distribution thereby eliminating traditional travel agencies as intermediaries. The ability to do this relies on a population that has access to and is comfortable with making online purchases. ${ }^{8}$ Internet usage is very high in the

\footnotetext{
${ }^{8}$ It bares remembering that internet usage can spread rapidly within a population. In 1998 in the UK, when LCCs were in their infancy, internet usage stood at $7.4 \%$, which grew to $26.8 \%$ in 2000 and to $70 \%$ by 2005 .
} 
Gulf states; in Bahrain, Qatar and UAE $90 \%$ of the population are using the internet. ${ }^{9}$ Saudia Arabia has a lower percentage of internet users (64\%) but usage grew 34\% between 2011 and 2014. In contrast, only 32\% of Egypt's population were internet users in 2014; a figure that was nevertheless $23 \%$ higher than 2011. Iran also has a lower percentage of internet users (39\% in 2014), but usage is growing fast with a $107 \%$ increase over 2011. More generally, forecasts of online travel market growth in the Middle East region appear to be positive. ${ }^{10}$

\section{Urban Development and Geography}

The degree of urban development combined with geographic dispersion and concentrations of population can provide an indication of the potential for growth in domestic short haul air travel within the MENA region. Table 3 shows the total population, the percentage of the total population living in urban agglomerations of more than one million people, the number of large and medium sized cities and the number of airport cities located at least $350 \mathrm{~km}$ from the city with the largest airport (based on passenger volumes).

Table 3: City Dwellers, Number of Large Cities and Distance Between Airport Cities by Country (2014).

\begin{tabular}{|c|c|c|c|c|c|}
\hline & $\begin{array}{c}\text { Population } \\
\text { (2014) }\end{array}$ & $\begin{array}{l}\% \text { of Total Population in } \\
\text { Urban agglomerations of } \\
\text { more than } 1 \text { million } \\
2011-2015\end{array}$ & $\begin{array}{l}\text { Number of } \\
\text { cities with } \\
\text { population } \\
>1,000,000\end{array}$ & $\begin{array}{c}\text { Number of cities } \\
\text { with population } \\
500,000- \\
1,000,000\end{array}$ & $\begin{array}{l}\text { Number of airport } \\
\text { cities } 350 \mathrm{k} \text { or more } \\
\text { from the city with } \\
\text { the largest airport }\end{array}$ \\
\hline Algeria & $38,934,334$ & $7 \%$ & 1 & 3 & 7 \\
\hline Bahrain & $1,361,930$ & .. & 0 & 1 & 0 \\
\hline Iran, Islamic Rep. & $78,143,644$ & $26 \%$ & 8 & 5 & 10 \\
\hline Iraq & $34,812,326$ & $27 \%$ & .. & .. & .. \\
\hline Kuwait & $3,753,121$ & $71 \%$ & 2 & 0 & 0 \\
\hline Oman & $4,236,057$ & .. & 0 & 0 & 1 \\
\hline Qatar & $2,172,065$ & .. & 0 & 1 & 0 \\
\hline Saudi Arabia & $30,886,545$ & $46 \%$ & 4 & 4 & 8 \\
\hline United Arab Emirates & $9,086,139$ & $51 \%$ & 3 & 0 & 0 \\
\hline Egypt, Arab Rep. & $89,579,670$ & $26 \%$ & 4 & 2 & 9 \\
\hline Israel & $8,215,300$ & $57 \%$ & 0 & 0 & 1 \\
\hline Jordan & $6,607,000$ & $17 \%$ & 1 & 1 & 0 \\
\hline Lebanon & $4,546,774$ & $48 \%$ & 1 & 0 & 0 \\
\hline Morocco & $33,921,203$ & $23 \%$ & 2 & 6 & 4 \\
\hline Tunisia & $10,996,600$ & $18 \%$ & 1 & 2 & 3 \\
\hline
\end{tabular}

Sources: World Bank ${ }^{11}$; citypopulation.de; Google maps.

\footnotetext{
${ }^{9}$ Based on number of internet users (for all devices including mobile phones) per 100 people between 2011 and 2014 (World Bank: http://data.worldbank.org/indicator/IT.NET.USER.P2)

${ }^{10}$ For example, Phocuswright (2015) forecast that online travel bookings will grow to $36 \%$ of total bookings by 2018.
}

${ }^{11}$ See data.worldbank.org/indicator/EN.URB.MCTY.TL.ZS 
Some (geographically) smaller countries (Kuwait, Israel, UAE and Lebanon) have a large percentage of the population living in urban agglomerations with the population concentrated in one or two cities; little potential for a domestic LCC network. However some larger countries show a significant degree of urban development and a potential for growth in domestic air travel. With a total population of around 31 million people, KSA has a significant amount of urban development with $46 \%$ of the population living in relatively large cities. In addition, there are eight airport cities located at least $350 \mathrm{~km}$ from Jeddah. Iran with a large population of around 78 million currently has 13 cities with a population of more than 500,000 with $26 \%$ of the population living in large urban areas. In addition to urban concentrations, Iran has 10 airport cities that are at least $350 \mathrm{~km}$ from Tehran. Egypt also has potential in this regard, with nine cities more than $350 \mathrm{Km}$ from Cairo however the country does not perform well on any of the other indicators.

In addition to the measures of urban development and geography, one can also consider the state and development of the airport network within a country. Iran and KSA have a larger numbers of passengers spread across several airports, while UAE demonstrates its hub role with a very large volume of passengers distributed over a cluster of three proximate airports. Egypt and to some extent Morocco and Tunisia also have domestic airport networks in which capacity is diffused rather than concentrated at one location.

\section{Spending by Foreign Visitors}

Figure 1 and Figure 2 show the recent trend in spending by foreign visitors. While foreign visitor spending is growing in some Gulf states, not surprisingly, it represents a small part of the economies of oil exporting countries, remaining steadily at or below $5 \%$ of the value of total exports since the mid-2000's. ${ }^{12}$ For oil importing MENA countries, spending by foreign visitors represents a more important sector of the economy, ranging from 5\% (Israel) to 35\% (Jordan). Figure 2 shows how Egypt in particular suffered a significant decline in foreign visitor spending following the 'Arab Spring' uprising in 2011. More recently the terrorist bombing of a Russian aircraft departing from the popular tourist destination Sharm Al Sheikh represents another negative shock to inbound tourist travel to Egypt.

\footnotetext{
${ }^{12}$ World Travel and Tourism Council (2016) Data Gateway: http://www.wttc.org/datagateway/
} 
Figure 1: Spending by Foreign Visitors (millions of real \$US);

Oil exporting MENA countries; 2006-2015

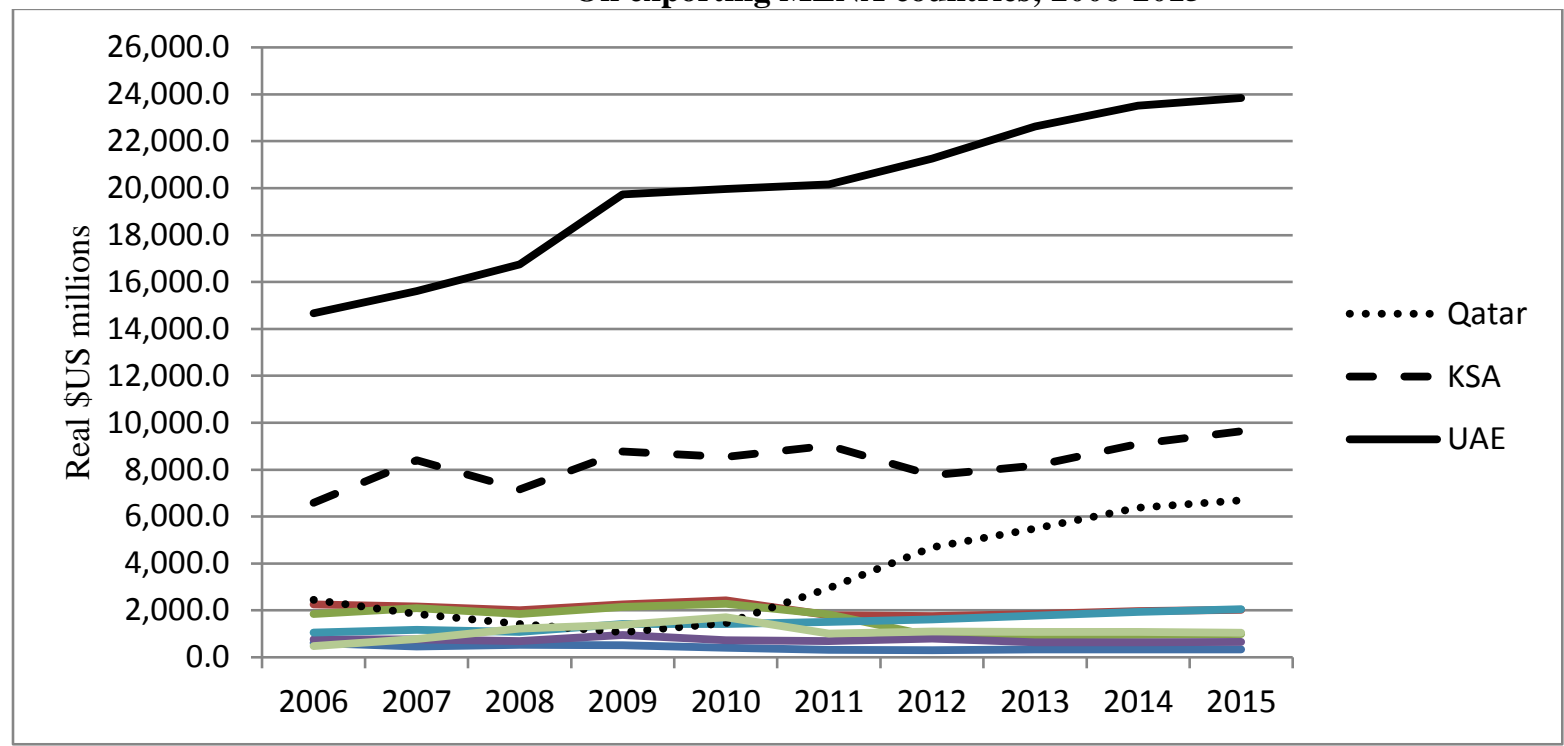

Source: World Travel and Tourism Council (2016)

Figure 2: Spending by Foreign Visitors (millions of real \$US);

Oil importing MENA countries; 2006-2015

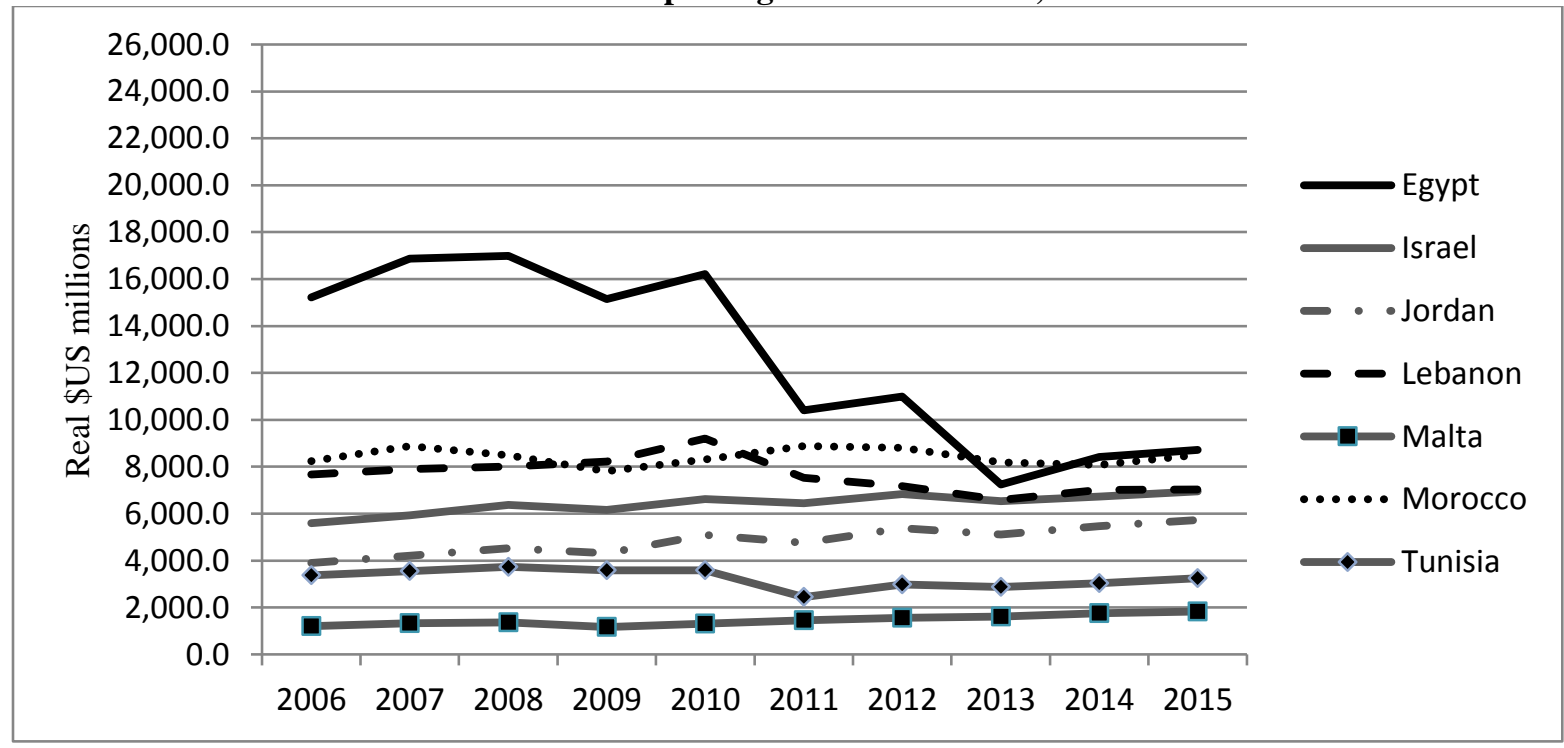

Source: World Travel and Tourism Council (2016)

\section{Overall Assessment}

From the five indicators outline above, Iran emerges with one of the strongest potentials for growth in LCCs. The only category in which Iran does not perform well (foreign visitor spending) is due to economic sanctions and restrictions on trade imposed and recently by the US 
and Europe. The other top performer is KSA which, like Iran, performs well on all metrics except foreign visitor spending. However in this category KSA does show positive growth. Of the oil importing countries, only Egypt and Morocco indicate a potential for a growth in domestic demand for LCC's however neither of these countries performs well on the other metrics. As a country with potential to increase inbound LCC traffic, Israel shows the most potential of the oil importing countries especially since it is the latest MENA country to sign an 'open skies' agreement with the Europe.

\section{Air Transport Liberalization}

An important element in creating opportunities for LCCs is the liberalization of air transport markets (Itani, O'Connell and Mason, 2015). In Europe the evolution of LCCs occurred in tandem with liberalization (Mason Morrison and Stockman, 2013) and there can be little doubt that the removal of restrictive bilaterals have had a significant impact on the success of the LCC business model. ${ }^{13}$

Historically, MENA countries have lagged behind the rest of the world in terms of the restrictiveness of the environment governing air travel. Bochert et al (2013), construct a trade restrictiveness index for cross border air passenger transport and find that in 2005, high income Gulf countries had the most restrictive environment for cross-border air transport compared with other Middle Eastern countries. In their study, the trade restrictiveness index for high income Gulf countries is almost double that of high income OECD countries; a result which reflects a relative lack of success in achieving intra-regional liberalization in air transport, despite attempts in both Africa and the Middle East to do so.

In 1999, the Council of Arab Transport Ministers formed an agreement to liberalize air transport through a gradual easing of regional restrictions on Middle-Eastern carriers in existing air service agreements. Schlumberger and Weisskopf (2012) report that following the 1999 agreement, some 17 'open skies' agreements (OSA's) were signed between a subset of Arab countries and in 2004, a regional OSA (the 'Arab League Open Skies Agreement') was

\footnotetext{
${ }^{13}$ Whether liberalization was a sufficient rather than a necessary condition for the magnitude of success enjoyed by LCCs in Europe is more complex question to answer because there were other contemporaneous elements which contributed to the growth of LCCs. Internet technology and aircraft leasing became predominant in the 1990's and both allowed LCCs to enter the market and compete more easily and effectively with incumbent legacy carriers. In addition, several negative shocks (the outbreak of SARS, September $11^{\text {th }}$ attacks and the Iraq war for example) contemporaneously weakened the competitive position of full service carriers.
} 
developed by the Arab Civil Aviation Commission. ${ }^{14}$ However only a few countries have ratified the agreement (Jordan, Palestine, Syria, UAE and Yemen) despite the prospective economic benefits from doing so.

African countries have a long history of attempts at liberalization dating back to the 'Yamoussoukro Declaration' in 1988. ${ }^{15}$ In 1999, the 'Yamoussoukro Decision' formalized agreement between 44 African countries to implement full liberalization of access to all routes, capacity, frequency and tariffs including provisions for the granting of $3^{\text {rd }} 4^{\text {th }}$ and $5^{\text {th }}$ freedoms to African carriers, and for competition and international safety standard compliance. ${ }^{16}$ Some 17 year later, the Yamoussoukro Decision has yet to be implemented, due at least in part to continued protectionism and inefficient use of air transport infrastructure. ${ }^{17}$

Notwithstanding the lack of progress in regional liberalization, individual MENA countries have taken steps towards more liberalized trade in air services via bilateral and multilateral OSAs. Table 4 shows the number of bilateral air service agreements (ASAs) and OSAs signed by each MENA country between 2000 and 2014. A total of 63 bilateral ASAs were signed during this period of which $41 \%$ included ' 5 th $F$ Freedom' rights, which are not customarily included in ASAs. ${ }^{18}$ The majority of ASAs have emanated from oil producing Gulf states and moreover UAE has been particularly aggressive in signing OSAs, claiming to have ratified approximately 78 such agreements prior to $2012 .{ }^{19}$ More recently, Emirates within the UAE have signed OSAs with Finland (2013); Cuba (2014); Burkina Faso (2015); Gabon (2015); Kuwait (2015); Sierra Leone (2015) and Slovakia (2015).

While the number of air service agreements since 2005 signal a move - particularly in the Gulf states - to liberalize access to air transport markets, other restrictions remain regarding ownership and control, subsidies to domestic (national) carriers and domestic regulations.

\footnotetext{
${ }^{14}$ Countries signing OSAs included Bahrain, Jordan, Lebanon, Morocco, Oman, Qatar, Syria and UAE.

${ }^{15}$ See Schlumberger (2010).

${ }^{16}$ See IATA-interVISTAS (2014).

${ }^{17}$ See interVISTAS (2014) and Njoya (2016) for example.

${ }^{18}$ Fifth freedom of the air is the right of an airline to carry passengers from its home country to country A, then pick up passengers and fly to country B. An example would be the right of Saudia to fly from Riyadh to London (where passengers enplane) and then on to New York. Sixth freedom rights enable an airline to carry passengers from country B via its home country en route to country A. An example would be the right of Emirates to pick up passengers in Mumbai, then fly to Dubai and then on to London.

${ }_{19}$ The signatories to Air service agreements in UAE are often individual emirates or combinations of emirates within the federation and so it is difficult to ascertain which agreements apply to which emirates. To date I have been unsuccessful in finding any source which catalogues the signatories and details of these agreements.
} 
Table 4: Bilateral and 'Open Sky' Agreements; MENA Countries (2000-2014) $)^{20}$

\begin{tabular}{|c|c|c|c|c|c|}
\hline MENA Countries & $\begin{array}{c}\text { Bilateral air } \\
\text { service } \\
\text { agreements }\end{array}$ & $\begin{array}{l}\text { Bilateral air } \\
\text { service } \\
\text { agreements }\end{array}$ & $\begin{array}{c}\text { Bilateral air } \\
\text { service } \\
\text { agreements }\end{array}$ & $\begin{array}{c}\text { Bilateral air } \\
\text { service } \\
\text { agreements }\end{array}$ & Open skies Agreements \\
\hline & 3rd 4th & 3rd,4th, 5th & $\begin{array}{c}\text { MENA } \\
\text { Countries }\end{array}$ & $\begin{array}{c}\text { Other } \\
\text { countries }\end{array}$ & \\
\hline Oil Exporting Nations & $2000-2014$ & $2000-2014$ & $2000-2014$ & $2000-2014$ & \\
\hline Algeria & 2 & 0 & 1 & 1 & \\
\hline Bahrain & 2 & 8 & 6 & 4 & $\begin{array}{l}\text { USA (1996); Singapore } \\
(2005)\end{array}$ \\
\hline Iran, Islamic Rep. & 9 & 0 & 7 & 2 & \\
\hline Iraq & 0 & 0 & 0 & 0 & \\
\hline Kuwait & 2 & 1 & 1 & 2 & $\begin{array}{l}\text { USA (2006); Brunei } \\
\text { (2009); UAE (2015) }\end{array}$ \\
\hline Libya & 0 & 0 & 0 & 0 & \\
\hline Oman & 4 & 3 & 2 & 5 & USA (2001) \\
\hline Qatar & 7 & 5 & 8 & 4 & Moldova (2015); \\
\hline Saudi Arabia & 7 & 1 & 5 & 3 & USA (2011) \\
\hline Syrian Arab Republic & .. & .. & .. & .. & \\
\hline United Arab Emirates & 0 & 3 & 2 & 1 & USA (1996) * \\
\hline Yemen, Rep. & 0 & 0 & 0 & 0 & \\
\hline \multicolumn{6}{|l|}{ Oil Importing Nations } \\
\hline Egypt, Arab Rep. & 1 & 0 & 0 & 1 & \\
\hline Israel & 0 & 0 & 0 & 0 & USA (2010); EU (2013) \\
\hline Jordan & 0 & 1 & 0 & 1 & USA (1996); EU (2010) \\
\hline Lebanon & 1 & 1 & 1 & 1 & \\
\hline Morocco & 1 & 1 & 2 & 0 & USA (2000); EU (2006) \\
\hline Tunisia & 1 & 1 & 1 & 1 & \\
\hline
\end{tabular}

Nevertheless, some state-owned carriers have moved away from 100\% state ownership to partial privatization (Royal Jordanian, Middle East Airways and Royal Air) and private management companies have replaced government departments or agencies in operating some airports in the region (Queen Alia International Airport, Madinah International Airport and Cairo International Airport).

\section{'Open Skies'Agreements with Europe: Morocco, Jordan and Israel}

To date, three MENA countries have signed OSAs with Europe; Morocco (2006), Jordan (2010) and Israel (2013). Figure 3 shows the trend of passenger volumes in Jordan and Morocco both prior to and after the agreements.

\footnotetext{
${ }^{20}$ WTO Quasar Database; www.wto.org/asap; US Department of State; www.state.gov/e/eb/tra/ata; European commission; ec.europa.eu/transport/modes/air/international_aviation/country_index/; www.wam.ae/en/news/economics/1395279009309.html.
} 
Figure 3: Total Airport Traffic (Passengers); Jordan and Morocco; 1998-2014 ${ }^{21}$

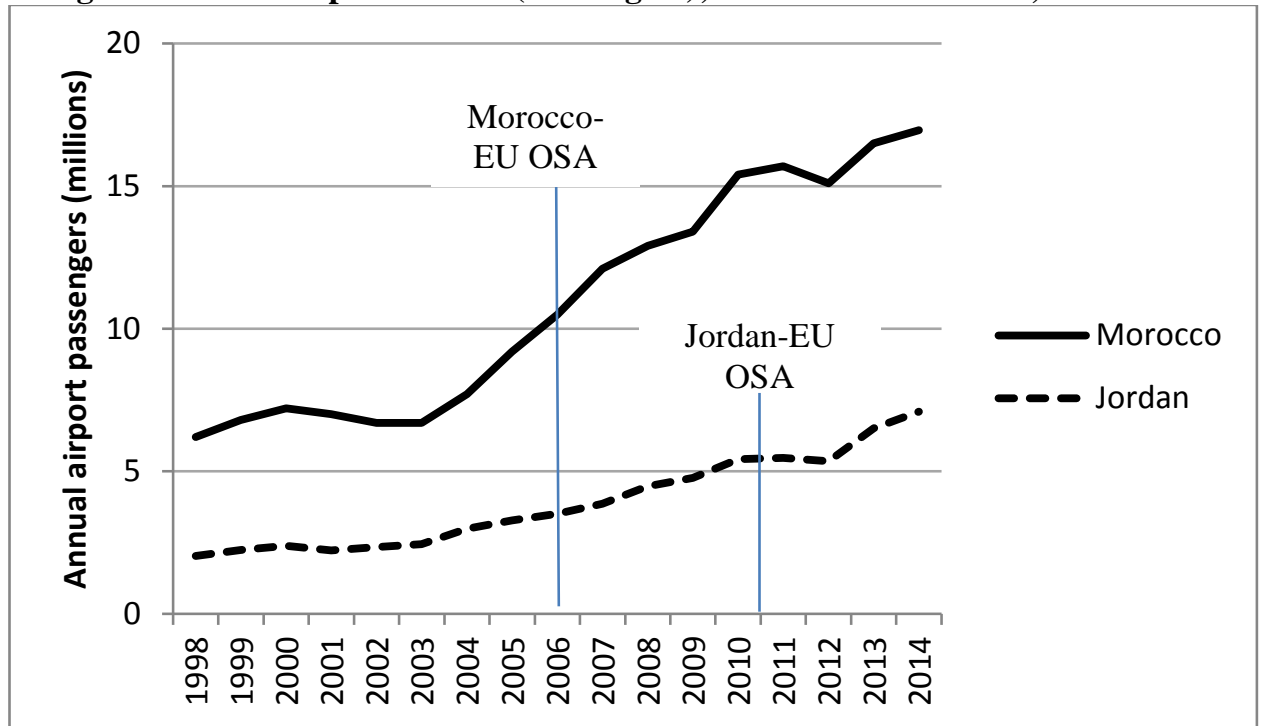

Sources: Anna Aero; Airport International Group; EHCAAN

In Morocco, a significant increase in the growth rate of passengers began as soon as negotiations to conclude the agreement were first anticipated (in 2004) and by 2014, total airport passengers in Morocco stood at 17 million compared to 6.7 million in 2003. LCCs were virtually non-existent in the Moroccan market prior to the OSA with Europe, however once the agreement was anticipated, LCCs began to increase their presence reaching a $42 \%$ market share in international traffic in 2010. This was followed by a downturn in 2011 and 2012 (see Table 6).

Table 5: LCC Percentage Share of Total Seat Capacity; Morocco 2004-2012

\begin{tabular}{|c|c|c|}
\hline & Domestic & International \\
\hline 2004 & 0.1 & 1.7 \\
\hline 2005 & 0.6 & 10.4 \\
\hline 2006 & 1.1 & 12.4 \\
\hline 2007 & 2.0 & 24.4 \\
\hline 2008 & 4.4 & 35 \\
\hline 2009 & 4.2 & 40.3 \\
\hline 2010 & 4.7 & 42.2 \\
\hline 2011 & 11.9 & 39.7 \\
\hline 2012 & 4.6 & 34.9 \\
\hline
\end{tabular}

Source: CAPA Centre for Aviation (2012)

In 2013, the top four LCCs (Jetairfly, Ryanair, easyJet and Air Arabia) accounted for $28.4 \%$ of total seat capacity with Royal Air Maroc's market share at approximately $50 \%{ }^{22}$ While

${ }^{21}$ Jordan passenger numbers do not include a small number of passengers at Aqaba Airport (estimated to be around 0.2 million in 2010) 
large, this market share actually represents a significant decline for the state-controlled flag carrier. In anticipation of market growth following the Moroccan-EU OSA, Royal Air Maroc added a significant amount of capacity and increased the number of its European destinations. ${ }^{23}$ Indeed, total air passenger traffic in Morocco increased by 67\% between 2005 and 2010, however over the same period, RAM suffered a drop in its market share from $71 \%$ to $55 \%$. By 2011 with a smaller share of a larger but more competitive market, RAM was in financial difficulty. Consequently the Moroccan government announced a package to improve the airline's performance which included a plan to partially privatize the airline, job cuts and a cash bailout of $\$ 193 \mathrm{~m}$. However RAM has continued to struggle, making losses in 2014 and 2015 and with no meaningful privatization having taken place. ${ }^{24}$ Morocco's OSA with Europe has thus led to a weakening of the incumbent state airline without the emergence of a successful domestic LCC.

Jordan's 2010 OSA with Europe coincided with the 'Arab Spring' and so air passenger traffic (which had grown at a modest rate prior to the open skies agreement) declined in 2012 but recovered in the following year and in 2014 Jordan had a total of approximately 7.1 million passengers; a 30\% increase over 2010. Unlike Morocco, European LCCs were not as quick to enter the Jordanian market. Ryanair has not offered service to Amman following the agreement and although easyJet did launch flights between London Gatwick and Amman in 2011, it withdrew from the route in 2014. Thus, while OSAs may have been a necessary condition for growth in Jordan's air transport sector such agreements may not have been sufficient to encourage growth in the low-cost sector at least via European airlines. ${ }^{25}$ However in 2014, Air Arabia Group purchased a 49\% stake in Petra Airlines and launched Air Arabia Jordan - which began offering service from Amman in 2015.

Israel is the most recent MENA country to sign an OSA with Europe. It's agreement, signed in 2013, calls for liberalization to be implemented over a five-year period ending in 2019. The response from European LCCs has been more in line with the Moroccan OSA, with easyJet expanding its service by $20 \%$ in 2014 and Ryanair commencing flights to Eilat Ovda airport in

\footnotetext{
${ }^{22}$ Source: OAG..

${ }^{23}$ RAM's available seat kilometers increase by $30 \%$ in 2006 over the previous year.

${ }^{24}$ The airline reported a net loss of approximately $\$ 28.1 \mathrm{~m}$ in 2014 (CAPA, 2015). Currently the government owns $96 \%$ of the airline while the remaining portion is held by Air France Group (3\%) and Iberia (1\%).

${ }^{25}$ There are two country-specific factors that perhaps make Jordan less attractive to European LCCs: first, unlike Morocco, Jordan does not have a large segment of the population working in European cities. Secondly, compared with Morocco, Jordan's location makes it a more distant destination in relation to European cities.
} 
2015. LCCs Norwegian and Wizz have also entered the market. Consequently in the first year of the agreement, the market share of LCCs in Israel grew to 8.8\% compared with 2.2\% in 2012. One potential source of protection for flag carrier El Al's market share is its enhanced security measures which are required by the Israeli government but also subsidized by up to $97.5 \%$ of the additional costs. People traveling to Israel and especially Jewish travelers with a willingness to pay for enhanced security will represent a source of loyalty to a level of security service not replicated by LCCs.

Overall, the lack of success in regional liberalization of air transport in the Middle East and Africa represents a constraint on air transport growth and on the strategies and prospects for LCCs. Cristea et al (2015) find that Arab countries with more liberal policies have higher passenger volumes and more city pairs being served. Their results suggest that that a deepening of the Arab League OSA would result in a 30\% increase in air passenger traffic. Liberalization of access to markets under OSAs and ASAs are a move in the right direction however liberalization of ownership and control rules would eliminate the necessity for joint venture expansion strategies (currently employed by Air Arabia and fastjet) that involve creating new airlines in each country and would instead allow for consolidation and cost efficient expansion of LCCs into new markets.

\section{LCCs in the MENA Region}

In any air transport market, one might reasonably expect to observe both entry and exit of LCCs over time, both as fighting brands created by traditional incumbents and as newly created airlines. Mason et al (2013) indicate that between 1995 and 2010, a total of 110 airlines entered the European market as LCCs of which 39 evolved from or were created by existing (traditional) carriers. By 2010 only 32 LCCs in total and only nine out of the 39 'evolved' airlines were still in operation. Of the $78 \mathrm{LCCs}$ that exited the European market, 30 were in business for one year or less. ${ }^{26}$ While at an earlier stage in the development of the low cost sector, the MENA region has also witnessed both successful and unsuccessful attempts to enter the LCC sector.

\footnotetext{
${ }^{26}$ See Mason et al (2013) for full details of entry and exit in the European LCC sector during and following liberalization.
} 


\section{MENA-based LCCs That Have Not Survived}

Morocco's, OSA with Europe initially spurred the creation of two domestic LCCs; Atlas Blue and Jet4you. Royal Air Maroc created subsidiary Atlas Blue as a 'fighting brand' in 2004 despite evidence that this strategy has been largely unsuccessful for traditional carriers (Morrell 2005; Dennis, 2007). ${ }^{27}$ Jet4you was created in 2006 as a joint venture between Moroccan investors and TUI travel, a leisure travel company based in the UK. ${ }^{28}$ However neither of these airlines survived as MENA-based LCCs. Atlas Blue ceased operations in 2010 after having failed to realise expected cost savings (FlightGlobal, 2013) and in 2012 Jet4you (which had become solely owned by TUI Travel in 2008) was merged into the Belgian travel company Jetairfly. ${ }^{29}$

In the Middle East, Wataniya and Sama are two examples of MENA carriers that shared some LCC characteristics but yet did not succeed. Wataniya, based in Kuwait, exited the market in 2011 and appears to have chosen an unsustainable business model. The airline combined the use of Airbus A320 aircraft with a low seat density (122 seats) and a relatively large business class cabin. This strategy was unable to compete with full service airlines (who have larger route networks and strong brand identity) for premium business travellers while at the same time offering discounts and economy fares. In contrast, Sama was launched as an LCC in Riyadh in 2007 but exited the market in 2010. Two reasons cited for the airline's failure were fare caps on domestic routes mandated by the Saudi Arabian government and jet fuel subsidies awarded to Saudia (the national full service carrier) which made it impossible for Sama to complete. Thus on the one hand deficiencies in business strategy design led to failure however the (regulatory \& legislative) environment also played a role

\section{MENA-based LCCs currently in operation}

Table 6 shows the growth in passenger volumes for MENA-based 'LCC' carriers currently in operation.

\footnotetext{
${ }^{27}$ More recently, Israel's flag carrier El Al has also adopted the fighting brand strategy with the creation of a new LCC subsidiary named 'UP' which began operations in 2014.

${ }^{28}$ Moroccan investors in Jet4you included Attijariwafa Bank; one of the largest banking and financial groups in Morocco.

${ }^{29}$ Jetairfly is the trading name of TUI Airlines Belgium.
} 
Table 6: Passenger Volumes and Compound Annual Growth Rate (CAGR) for MENA 'LCCs'; 2010-2015

\begin{tabular}{|l|r|r|r|r|r|r|r|}
\hline Passengers (000s) & $\mathbf{2 0 1 0}$ & $\mathbf{2 0 1 1}$ & $\mathbf{2 0 1 2}$ & $\mathbf{2 0 1 3}$ & $\mathbf{2 0 1 4}$ & $\mathbf{2 0 1 5}$ & \multicolumn{1}{c|}{ CAGR } \\
\hline Jazeera & 1131 & 1153 & 1,129 & 1,140 & 1,165 & 1,218 & 1.5 \\
\hline Flydubai & 848 & 1410 & 4,940 & 6,820 & 7,250 & 9,040 & 60.5 \\
\hline Air Arabia & 4456 & 4696 & 5,301 & 6,108 & 6,817 & 7,460 & 10.9 \\
\hline FlyNas & 2036 & 2041 & 2,865 & 3,503 & 4,679 & 5,800 & 23.3 \\
\hline
\end{tabular}

Source: OAG

A high degree of variability in passenger growth is evident in the CAGR for these airlines. Jazeera, which is more focused on intra-region markets has the lowest CAGR while Flydubai which has focused on coordinating inter-regional flights with longhaul carriers has enjoyed an impressive $60.5 \%$ CAGR. Both Air Arabia and FlyNas have also enjoyed strong growth. Are these differences in growth rates a result of a different strategic approach's within an overall LCC business model? Consider Europe's most successful LCCs (easyJet and Ryanair) as a benchmark with which to compare the business strategies of MENA-based 'LCCs'. As a first pass we compare characteristics which are commonly used to distinguish LCCs from traditional 'full service' carriers. ${ }^{30}$

Table 7: Comparing LCC Characteristics

\begin{tabular}{|l|c|c|c|c|c|c|}
\hline \multicolumn{1}{|c|}{ LCC Characteristics } & Ryanair & easyJet & flydubai & $\begin{array}{c}\text { Jazeera } \\
\text { Airways }\end{array}$ & flynas $^{31}$ & Air Arabia \\
\hline Single aircraft type & Yes & Yes & Yes & Yes & Yes & Yes \\
\hline Point-to-point network & Yes & Yes & Yes & Yes & Yes & Yes \\
\hline Block hours per day (aircraft utilization) & 8.5 & 10 & 13 & 13 & 12 & 14 \\
\hline Average sector length (miles) & 790 & 650 & 3,200 & 750 &.. & 1,200 \\
\hline Predominant use of secondary airports & Yes & No & No & No & No & No \\
\hline One cabin class & Yes & Yes & No & No & No & Yes \\
\hline Hold baggage included in fare (econ) & No & No & Sometimes & Yes & Yes & No \\
\hline Meals/snacks/drinks included in fare (econ) & No & No & No & Yes & No & No \\
\hline
\end{tabular}

Sources: Schlumberger and Weisskopf (2014), airline websites.

Table 7 makes it immediately apparent that there are differences between MENA-based LCCs and their European counterparts. Only two LCC characteristics are shared by all the airlines in Table 7 namely 'single aircraft type' and 'point-to-point network'. MENA-based LCCs typically have more block hours per day than either easyJet or Ryanair and do not utilize secondary airports. Air Arabia and flydubai have significantly longer stage lengths than either

\footnotetext{
${ }^{30}$ See for example Williams et al (2003).

${ }^{31}$ Prior to fall 2014 flynas included long-haul flights in its route network and consequently had a mixed fleet and longer average stage lengths. However, in 2014 flynas ceased scheduled long-haul flights to focus on short-haul and has moved to a uniform fleet (Airbus A320).
} 
easyJet or Ryanair and three of the four MENA LCCs offer a business class cabin while two airlines include a checked baggage allowance with an economy fare. Jazeera Airways is unique in also including meals, snacks and drinks in an economy fare. Of the four airlines, flydubai's business model is perhaps the least like an LCC because of the airline's integration with longhaul operators (including Emirates and Qantas) which allows passengers to purchase their travel to a flydubai destination on a single ticket and to have their luggage checked through to the connecting flight in Dubai. flydubai offers a total of 89 destinations of which 33 are in the MENA region. Non-MENA destinations include eastern Europe, India, and Pakistan giving the airline an average sector length that is almost five times that of EasyJet. Thus flydubai's business model is more akin to that of a regional carrier servicing the connectivity demands of full-service airline passengers.

In contrast to flydubai, Air Arabia Group, founded in 2003 shares five of the eight characteristics listed in Table 7 with easyJet and Ryanair. The Air Arabia Group currently has a 95 destinations, of which 46 are within the MENA region, 17 are to EU countries and Switzerland and 32 are to other international destinations including Urumqui in China (a route that falls within the range of its A320 aircraft). Air Arabia has negotiated rights to serve other more distant Chinese cities but has elected to wait until future generations of the A320 aircraft have a sufficient range to reach them rather than deviate from operating a single aircraft type. This aversion to operating a mixed fleet appears to be one of the core elements of the LCC sector (see Table 7). ${ }^{32}$

While Air Arabia seems to be following more closely in the footsteps of easyJet and Ryanair compared with other MENA-based 'LCCs' there are some more subtle differences. For example, while Air Arabia offers a single economy cabin, its seating density is significantly lower than either easyJet or Ryanair (between 162-168 seats with an interior seating design that offers a seat pitch of 32 inches which is above average for economy seats). ${ }^{33}$

\section{Benchmarking LCC business models}

To look more closely at LCC strategies in the MENA region as compared with European LCCs, we employ a benchmarking framework for consistently assessing the business models of

\footnotetext{
32 flynas experimented with a operating a mixed fleet which included wider body aircraft as part of a strategy to offer low cost, long haul service to some Asian cities - a strategy that it eventually abandoned in 2014.

${ }^{33}$ This compares with 30 inches and 29 inches for Ryanair and easyJet respectively.
} 
airlines as first suggested by Morrison \& Mason (2006), operationalised by Mason and Morrison (2008) and extended by Mason, Morrison and Stockman (2013). The analysis takes a 'product and organizational architecture' (POA) approach to assess how product/service design, benefit drivers (value creation), input choice and cost efficiency interact with a firm's organizational design to generate profits. ${ }^{34}$ A conceptual illustration of POA analysis is provided below in Figure 4.

Figure 4: Product and Organizational Architecture Analysis of Business Strategy

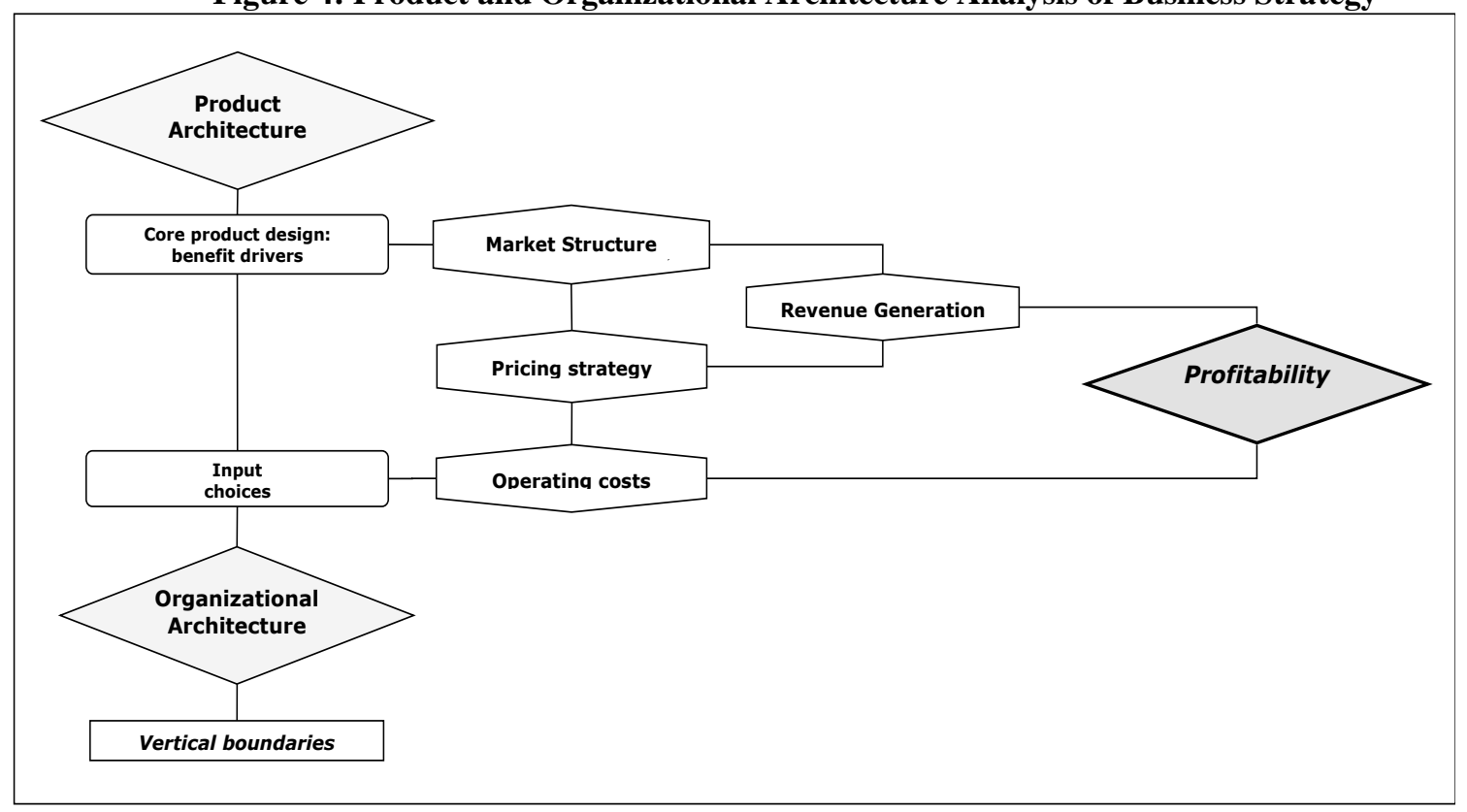

As suggested in Figure 4 the design of a firm's product or service offering will define a core product bundle that creates consumer surplus (i.e. creates value) relative to the firm's pricing strategy which in turn is influenced by the market structure. Additionally however, product design also has implications for costs of production (which impacts pricing strategy) and organizational structure (what is produced internally and what is contracted out for example) Taken together, both product and organizational architecture contribute to the creation and sustainability of profits.

As an implementation of POA analysis, Morrison and Mason (2006) developed a set of measurable indices to capture the inter-relationships between an airline's core product, its cost and revenue structure, productivity factors, airports characteristics and market structure. ${ }^{35}$ These

\footnotetext{
${ }^{34}$ See Mason and Morrison (2008) for a more detailed discussion of the POA model as it relates to airline business strategy

${ }^{35}$ Complete details of the methodology and calculation of indices can be found in Mason and Morrison (2008).
} 
descriptors of the business strategy are then related to the overall cost structure and the ability to generate revenues and ultimately profits. Ten market, performance and product indices are built using 37 individual data items for each of the airlines incorporated in the benchmark analysis (see the Appendix). What emerges is a representation of each airline's business strategy, relative to other benchmarked airlines.

With regard an airline's core product bundle, the analysis focuses on three key sets of elements that create consumer value: connectivity, convenience and comfort. Connectivity refers to the type and extent of the airline's route network. Increased connectivity holds value for consumers but can also increase costs. Connectivity is measured using three components; network density (departures per airport per day), number of routes offered and all destinations offered at airports served. These three indices thus measure the value proposition inherent in the service that an airline elects to provide for its customers.

The convenience index is composed of average weekly frequency per route, average distance of airports from the nearest population centre, the percentage of flights from 'primary' airports, punctuality (percentage of on-time departures and arrivals) and a baggage service quality rating (provided by Skytrax). ${ }^{36}$ Lastly, the comfort index is composed of four elements; average number of passengers per flight, number of cabin crew per flight, economy seat width and economy seat pitch.

In addition to these indices, indices for aircraft productivity, labour productivity, airport attractiveness, distribution and market structure are also constructed. Finally, indices are calculated for overall costs, revenues and profitability. ${ }^{37}$ As outlined in Mason and Morrison (2008), correlation coefficients between individual elements in each index and operating profits can be calculated and used as weights in the construction of each overall index value. These indices are then benchmarked against the 'best-in-class' for a reference group of airlines. What emerges is a representation of each airline's business strategy, relative to the other carriers in the reference group.

Mason, Morrison and Stockman (2013) use this approach to characterize two distinct stylized business models within the LCC sector. They term these the 'truly low cost' model and the 'full

\footnotetext{
${ }^{36}$ The term 'primary airport' is defined as having 10 or more network carriers operating from the airport. Examples of primary (secondary) airports include; Frankfurt (Frankfurt-Hahn), Hamburg (Hamburg-Lubeck), Glasgow (Glasgow-Prestwick), LondonLuton, and Paris CDG (Paris-Orly).

${ }^{37} \mathrm{~A}$ full listing of the indices and their components is shown in Appendix 2.
} 
service competitor' model. The 'truly low cost' model is a business strategy with an unflinching focus on low costs. The elements of this model are as follows:

- Costs drive everything - be the lowest cost competitor

- Fly to secondary airports

- Offer low levels of convenience, comfort and connectivity

- Strive for high aircraft utilization and productivity

- Strive for low aircraft maintenance costs (fleet uniformity)

- Strive for high labour productivity

- Offer low fares

- Compete aggressively on price to achieve market power in city-pair markets

- Trade off lower margins against high volumes and low costs to achieve profitability

This low cost focused business strategy is illustrated relative to the index categories developed by Mason and Morrison (2008) using a 'spider web' diagram as shown in Figure 5 where the outer perimeter of the web represents a 'best-in-class' score for each index. In Mason and Morrison (2008) the measured indices for Ryanair look strikingly similar to this stylized model as shown below in Figure 6. An alternative to the 'truly low cost' business strategy is the 'full service competitor' strategy (Mason Morrison and Stockman, 2013) which is focused less on cost and more on revenue generation and the capturing of market share for business travel.

Figure 5: A stylized 'Low Cost Focus’ LCC Business Strategy

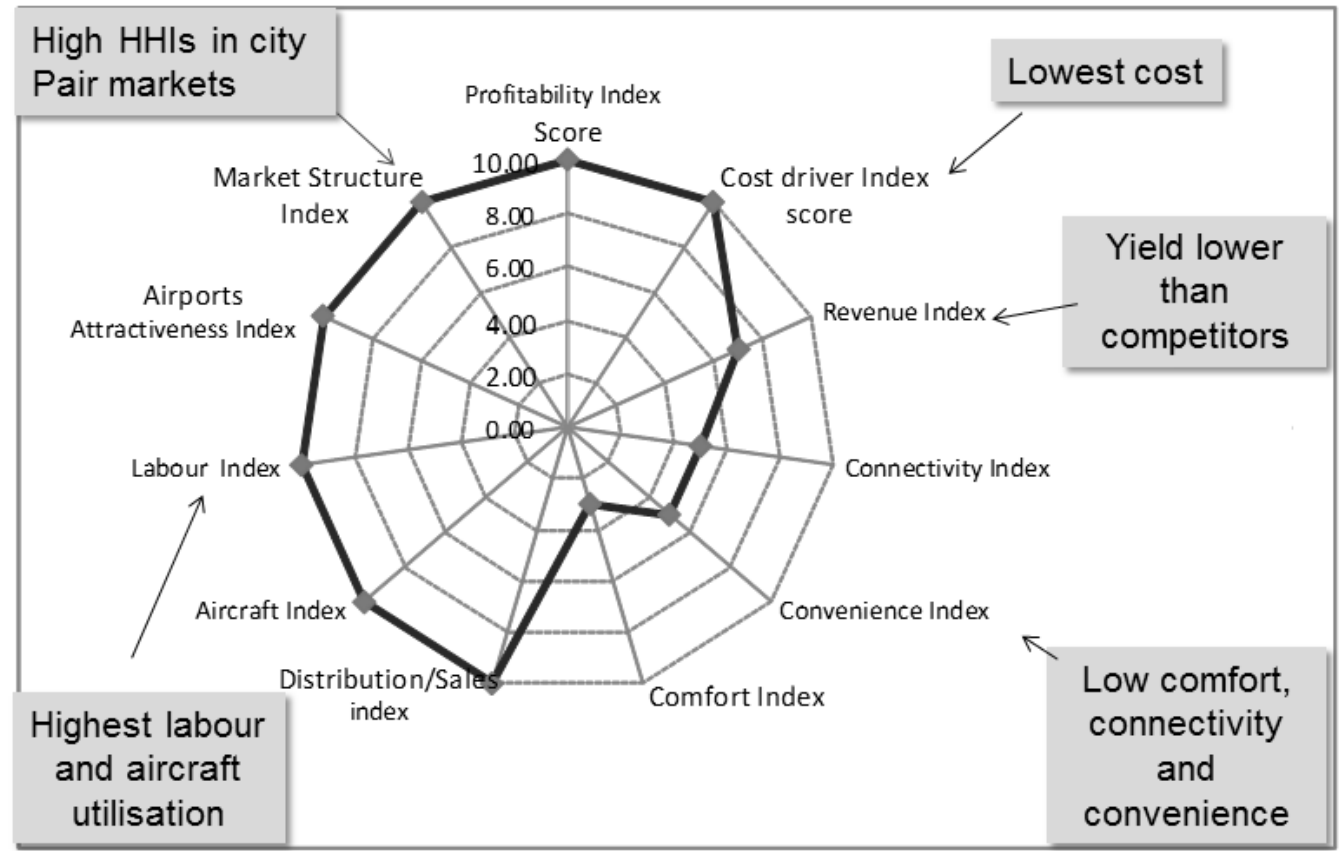

Source: Source: Mason, Morrison and Stockman (2013) 


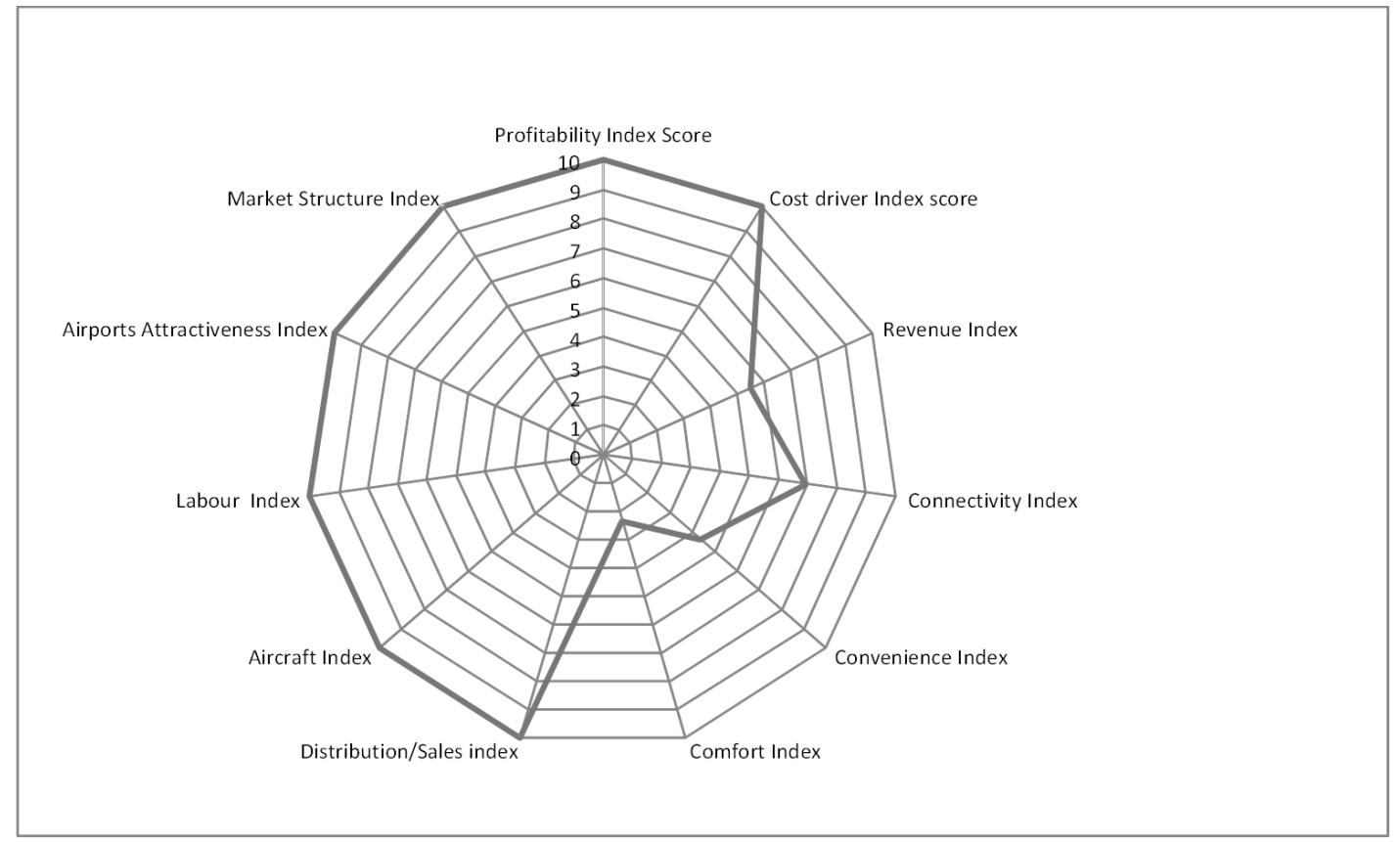

Source: Mason and Morrison (2008)

Key elements of the 'full service competitor' model (illustrated below in Figure 7) are:

- Offer higher levels of comfort, convenience, connectivity (compared with 'truly low cost')

- Fly to select primary airports

- Not focused on having the lowest costs, but striving to have lower costs than FS competitors

- Attempt to capture share in the business travel market

- Strive for lower costs through contracting out, operating a point-to-point network, operating a uniform fleet and efficient sales/distribution

The indices for easyJet calculated by Mason and Morrison (2008) (see Figure 8) map closely with this stylized 'full service competitor' model. While more focused on revenue generation, easyJet has retained several LCC characteristics.

\section{Comparing Air Arabia to easyJet and Ryanair}

The benchmarking analysis of LCC business strategies as outlined above can be employed to get a better picture of how a MENA-based LCC's business model is positioned relative to those of successful LCCs in Europe. Ideally we would want to include all the MENA-based airlines in this analysis however, Air Arabia is the only publicly traded company in the MENA region that. 
Figure 7: A stylized 'Full Service Competitor' LCC Business Strategy

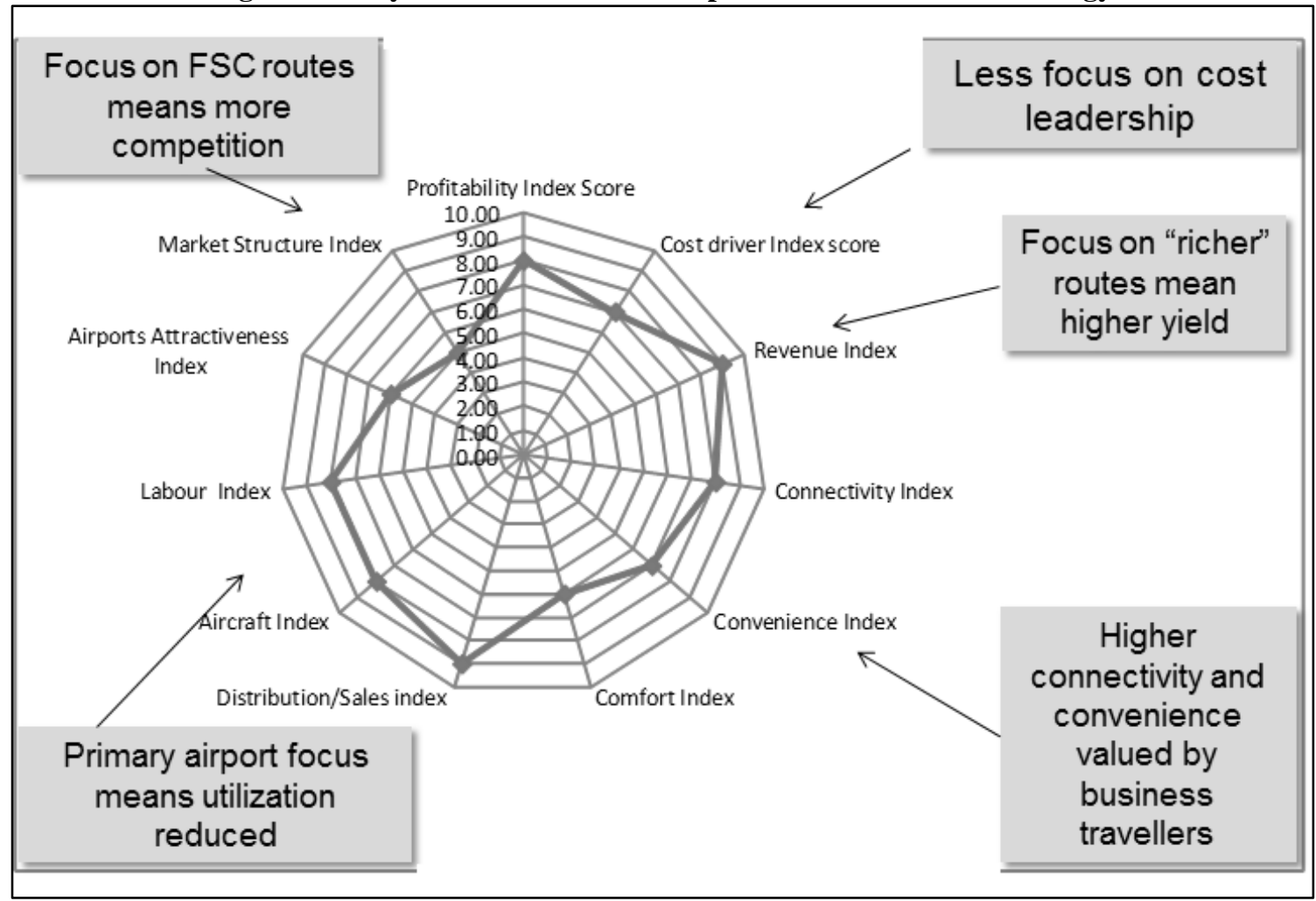

Source: Source: Mason, Morrison and Stockman (2013)

Figure 8: Benchmarked Indexes for EasyJet (2005)

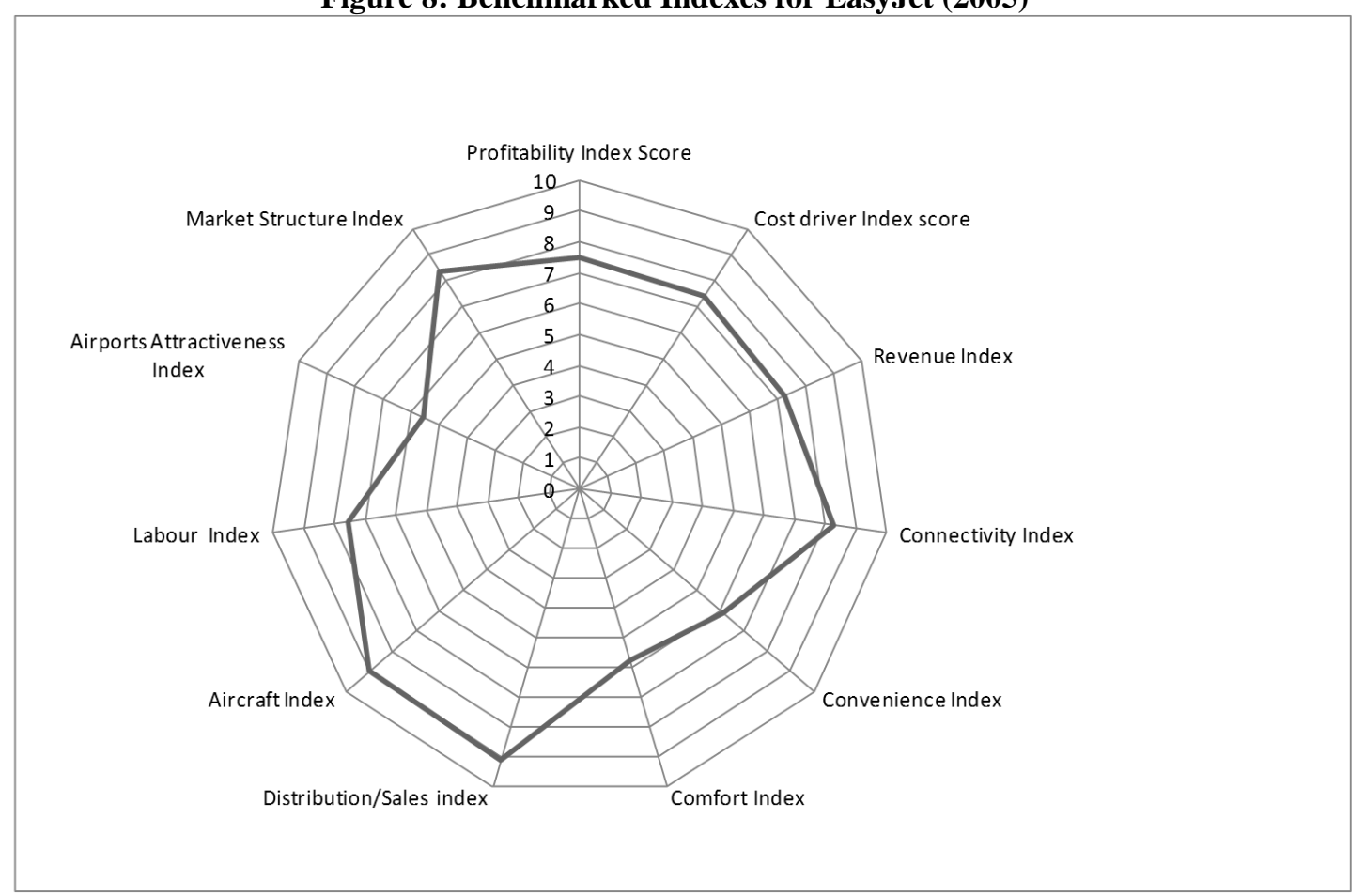

Source: Mason and Morrison (2008) 
provides fully audited accounts of sufficient detail. Consequently, for the remainder of this paper we focus on Air Arabia

To compare the business model of Air Arabia with those of easyJet and Ryanair, we have recalculated benchmarking indices using updated 2010 and 2014 data. The strategy map based on 2010 data suggests that Air Arabia has not followed either the 'truly low cost' model or the 'full service competitor' model but instead has followed a hybrid strategy. The measured indexes for Air Arabia are illustrated below in figure 9.

When compared with the strategies for Ryanair and easyJet, we can see that, Air Arabia's strategy is markedly different. Air Arabia's Labour and aircraft productivity indexes are low. In the former case, available seat kilometers per employee is half that of Ryanair's in 2010. While Air Arabia does achieve relatively high aircraft utilisation, the number of sectors flown per day is lower than either Ryanair or easyJet which reduces its productive capacity.

Figure 9: Benchmarked Indexes for Air Arabia (2010)

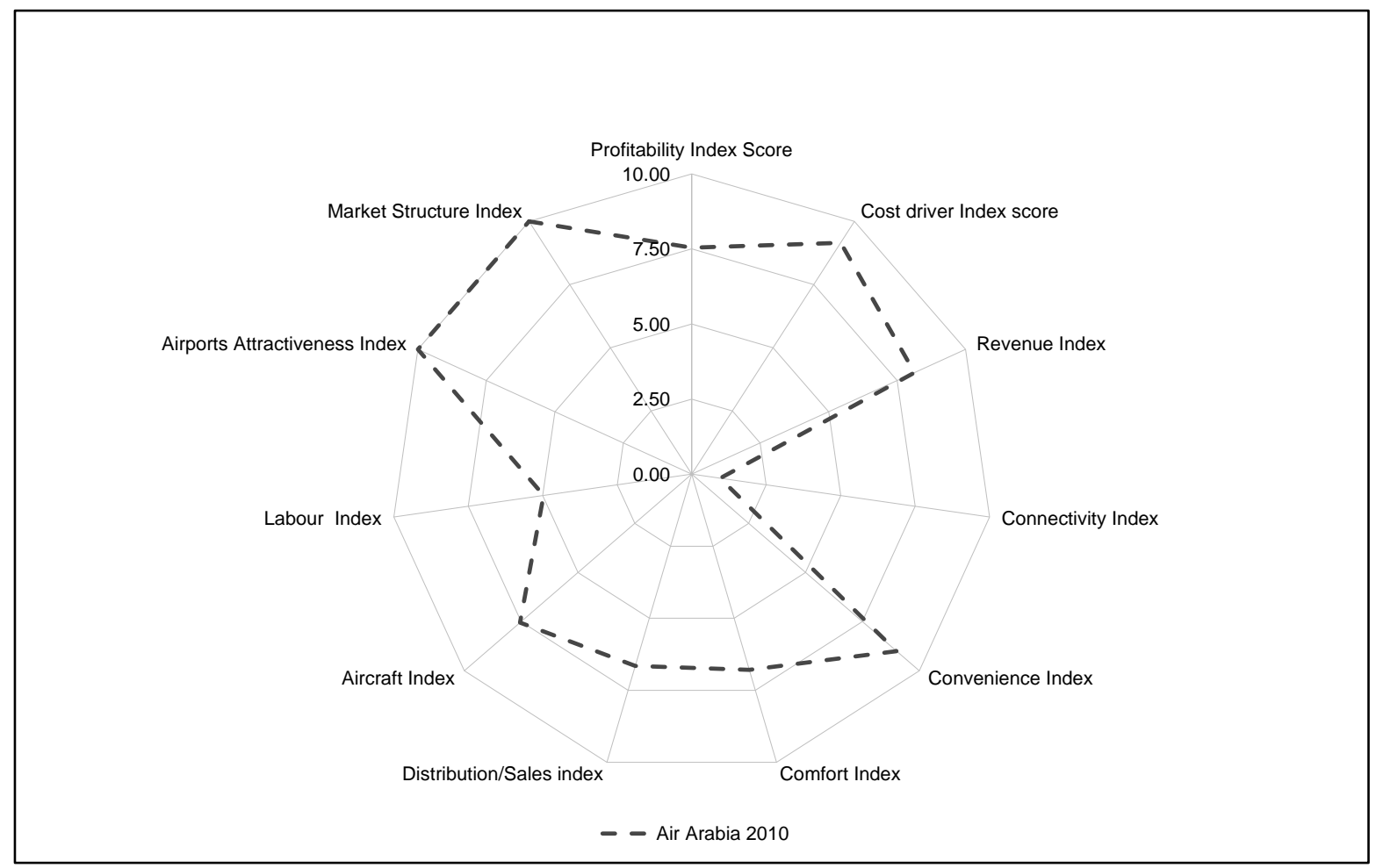

As pointed out in section 2, some countries in the MENA region have lower (although growing) internet usage rates and perhaps as a consequence, Air Arabia makes use of multiple 
sales channels which lowers the productivity of its sales and distribution index. In area of comfort, Air Arabia clearly offers higher levels of comfort compared to either easyJet or Ryanair. This is because of their higher seat pitch and smaller number of seats (162-168) compared to 180 for easyJet (being increased to 186 in 2016) and 189 for Ryanair. The extra comfort may translate into higher revenues for Air Arabia, but it also contributes to a higher cost per seat. Air Arabia also delivers a high level of convenience mainly because most of the airports it serves are primary airports coupled with a high punctuality rating. The market structure and airport attractiveness index measures for Air Arabia as reported here are incomplete (due to lack of data availability) however in 2010 the airline had little direct competition on many of its citypair markets (based from Sharjah). This helps to generate market power and keeps fares higher than they would be with more direct competition. In terms of airport attractiveness, the airline is dominant at its base in Sharjah where it and has a 50\% ownership stake and which keeps its airport costs low, however this is counterbalanced to some degree by its destination airports, all of which are large with many airline customers (lower airline bargaining power) and a significant number of full service airline competitors. This latter aspect of airport attractiveness is not fully represented in this calculation of the index (again due to data limitations).

\section{Air Arabia in 2014}

Business models, especially those in the airline industry, are not static but evolve over time. Figure 10 shows benchmarked indices for Air Arabia Group in 2014 as compared with 2010. The general 'shape' of Air Arabia's business model is roughly the same, but shows some improvement in labour productivity and profitability however the market structure index has weakened, likely caused by a combination of increased competition with flydubai and more airline competition at their destination airports. The airline displays a higher comfort index relative to 2010 but this has not translated into an improvement in revenues; again a sign of a more competitive environment. The airport attractiveness index for 2014 more accurately reflects Air Arabia's airport costs (although these are still estimates, given a sparsity of data) and as a result is slightly weaker than in 2010.

Comparing Air Arabia with Ryanair and easyJet in 2014 (see Figure 11) we can see that while the strategies of the European LCCs have evolved to some degree, Air Arabia's business model still differs significantly from each of them. Air Arabia's lower airport costs at Sharjah 
and their monopoly on $85 \%$ of their city-pair markets (on account of their dominance at Sharjah) displace Ryanair as 'best-in-class' in terms of airport attractiveness and market structure.

However, these results should be treated with caution due to data limitations and the fact that Sharjah and Dubai International are treated as different city-pair elements. While our benchmarking analysis suggests that Air Arabia is not following either of the stylized models associated with Ryanair and easyJet, Air Arabia is closer to the 'full service competitor' conceptual model given its comfort and convenience levels which enable the airline to compete with large full service carriers in the region. The airline is able to charge higher prices for this service value to some degree but has higher costs as a consequence.

Figure 10: Benchmarked Indexes for Air Arabia: 2010, 2014

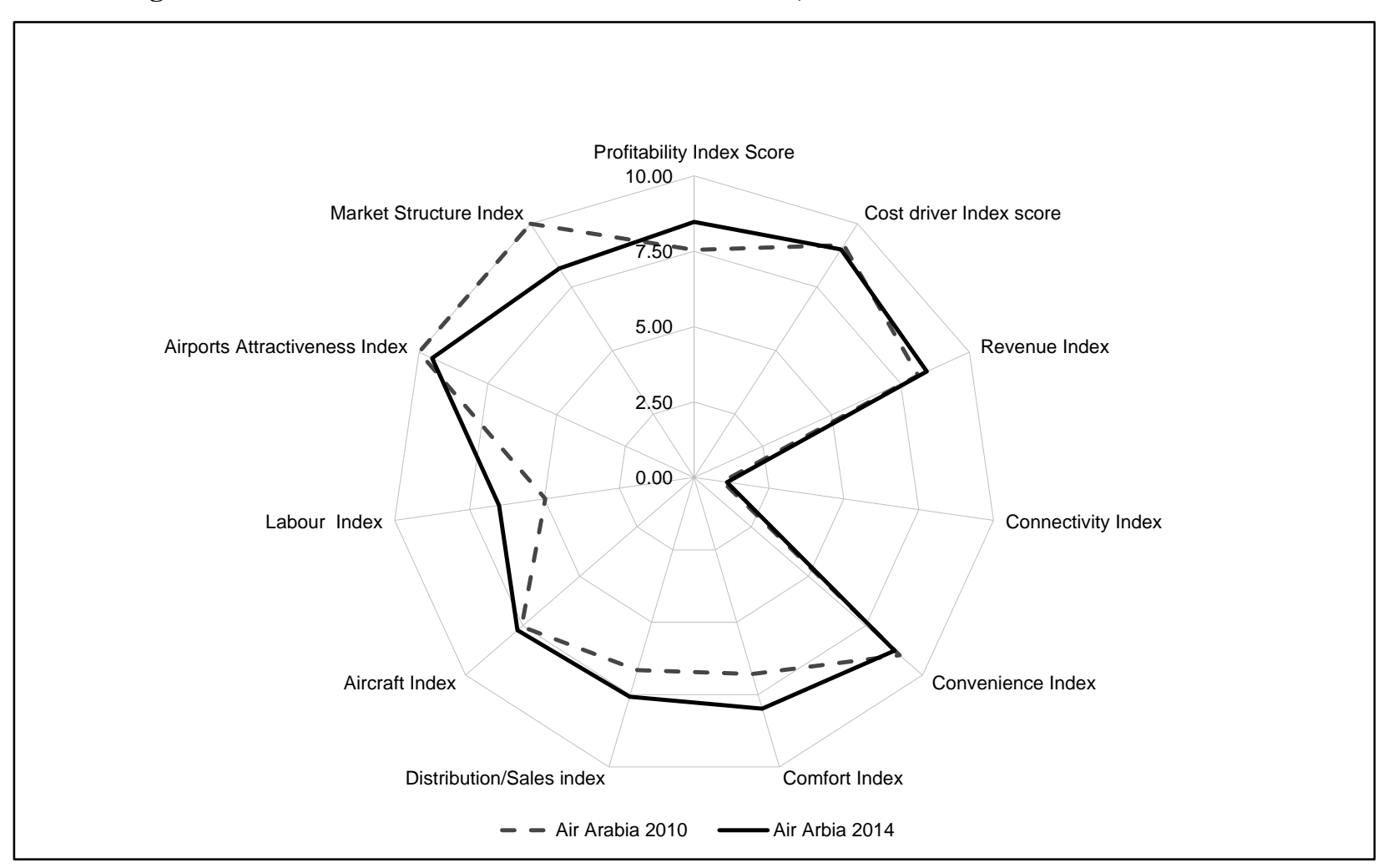

Figure 11: Benchmarked Indexes for Air Arabia compared with Ryanair and EasyJet (2014) 


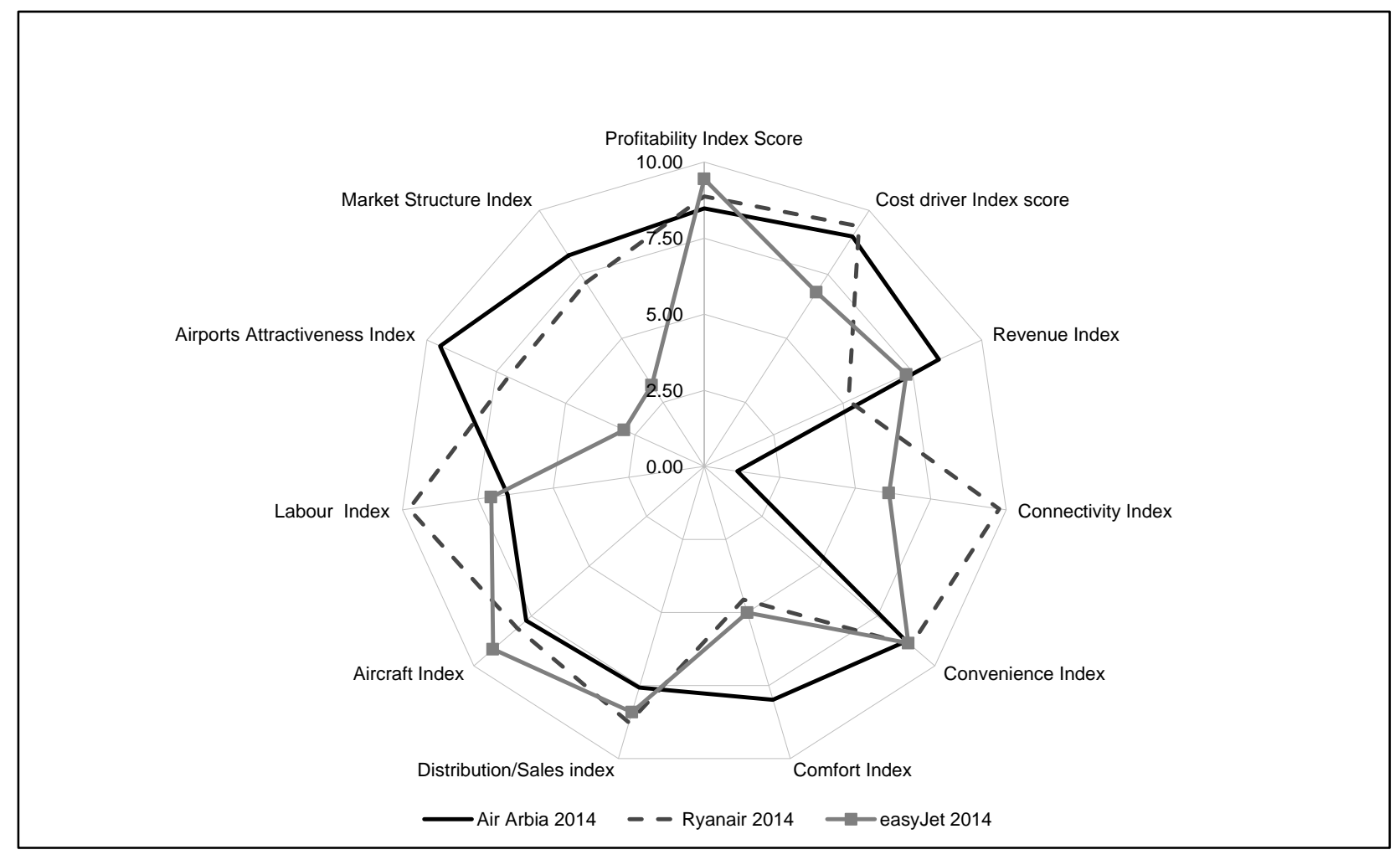

\section{Concluding remarks}

The economic development indicators we have outlined in this paper suggest future potential for LCC growth in MENA countries like Iran and Saudi Arabia while other MENA countries continue to face challenges in several dimensions. With regards to the role of macroeconomic growth in creating a positive environment for low cost air travel it should be noted that the most recent growth rates reported in this article are from 2014 and therefore do not capture the dramatic fall in the price of oil which represents a severe negative shock to the economies of oil exporting countries. While slower growth and lower oil revenues make the general environment less favourable for air travel, the current climate may have some positive implications for LCCs in the MENA region. With dwindling oil revenues, countries such as Saudi Arabia now have a stronger incentive to eliminate costly fuel subsidies to state carriers which would allow LCCs to compete more aggressively on price. Indeed, new LCCs are poised to enter the market; Al Maha Airways (a subsidiary of Qatar Airways) and SaudiGulf Airlines hope to begin services in KSA in 2016. Both airlines received delivery of their aircraft some time ago but have had to delay their start dates several as negotiations continue with government 
authorities. The elimination of fuel subsidies and the easing of price caps on domestic routes in KSA will pave the way for LCCs to take more market share away from the state carrier in the same manner that occurred in Morocco and is now occurring in Israel.

The apparent inability to advance regional liberalization in the Middle East and Africa, and the continued temptation to protect state-owned or flag-carrying carriers will inhibit the growth of the low cost sector. In the absence of broad regional liberalization, we can still expect more bilateral 'open skies' agreements. Tunisia is favoured to be the next MENA country to sign an OSA with Europe and more could follow. However as has been pointed out elsewhere, OSA's that provide unrestricted access to markets are only a partial element that should be expanded to include relaxation of ownership and control rules. ${ }^{38}$

Our analysis of business strategies suggests that in general, MENA-based 'LCCs' while retaining some core characteristics of the low cost model (single aircraft type and point-to-point networks) also differ in some important areas (multiple cabin classes, use of secondary airports). Our benchmarking analysis reveals that Air Arabia is is following a distinctly different business model from either easyJet or Ryanair. One might conjecture that the stages of economic development in MENA countries combined with a relatively less liberalized environment have redefined what it currently takes to be a successful LCC in the MENA region. In the future with a more liberalized environment and a growing middle class we can expect more entry by foreign LCCs (such as Turkey's Pegasus Airlines and AtlasGlobal Airlines for example) and the creation of new LCCs. What is not clear is whether today's dominant MENA-based LCCs will be able to adapt and survive in that market environment.

\footnotetext{
${ }^{38}$ For example see InterVISTAS (2009) on the additional benefits of ownership and control liberalization in conjunction with market access liberalization.
} 


\section{Bibliography}

AINonline.com. "African CEOs Deliberate Renewed Impetus for Open Skies" (November, 2015);

"http://www.ainonline.com/aviation-news/air-transport/2015-11-18/african-ceos-deliberate-renewed-impetus-openskies

Air Arabia. Financial Statements;

http://www.airarabia.com/en/financial-statements

Airport International Group. QAIA Traffic Statistics;

http://www.aig.aero/en/content/qaia-traffic-statistics

Al Arabiya Aviation and Transport. “Three years on, Saudi’s new airlines still grounded”, alArabiya.net (December, 2015);

http://english.alarabiya.net/en/business/aviation-and-transport/2015/12/30/Three-years-on-Saudi-s-new-airlines-stillgrounded-.html

Amadeus. "Middle East hub airports winning long-haul passenger traffic race", Amadeus.com (April, 2014);

http://www.amadeus.com/blog/16/04/middle-east-hub-airports-winning-long-haul-passenger-traffic-race

Anna Aero. “AtlasGlobal starts Sharjah sector”, anna.aero (April, 2016);

http://www.anna.aero/2016/04/05/atlasglobal-starts-sharjah-sector/

Anna Aero. "Morocco's airports grow passenger numbers by 9\% in 2013; easyJet and Ryanair lead way with most new routes", anna.aero (February, 2014);

http://www.anna.aero/2014/02/12/moroccos-airports-grow-passenger-numbers-9-2013-easyjet-ryanair-lead-waynew-routes/

Anna Aero. "Egypt's traffic up 35\% in three years; local start-ups attacking EgyptAir monopoly", anna.aero (February 2010);

http://www.anna.aero/2010/02/23/egypts-traffic-up-35pc-in-three-years/

Borchert, Ingo, Batshur Gootiiz, and Aaditya Mattoo. "Policy barriers to international trade in services: evidence from a new database." The World Bank Economic Review (2013): 1ht017.

CAPA Centre for Aviation. "Air Arabia prepares to launch a new Jordan-based airline as Royal Jordanian posts another loss", centreforaviation.com 2015;

http://centreforaviation.com/analysis/air-arabia-prepares-to-launch-a-new-jordan-based-airline-as-royal-jordanianposts-another-loss-218939

CAPA Centre for Aviation. "flynas returns to short-haul flying as Saudi Arabia welcomes Al Maha Airways and SaudiGulf Airlines", centreforaviation.com, 2014;

http://centreforaviation.com/analysis/flynas-returns-to-short-haul-travel-as-saudi-arabia-welcomes-al-maha-airwaysand-saudigulf-airlines-198614 
CAPA Centre for Aviation. "Arab Air Carriers show that not all are created equal, but the rest of the world can learn from them.", centreforaviation.com, (2013a);

http://centreforaviation.com/analysis/arab-air-carriers-show-that-not-all-are-created-equal-but-the-rest-of-the-worldcan-learn-from-them-143553

CAPA Centre for Aviation. Yearbook (2013b);

http://centreforaviation.com/about-capa/updates/capa-world-aviation-yearbook-2013-country-airline-data-in-acomprehensive-1000-page-report-109509

CAPA Centre for Aviation. "Jordan Continues to See No LCC Influx Despite EU Open Skies Agreement.", centreforaviation.com (June, 2012);

http://centreforaviation.com/analysis/jordan-continues-to-see-no-lcc-influx-despite-eu-open-skies-agreement-75713

Cristea, Anca D., Russell Hillberry, and Aaditya Mattoo. "Open skies over the Middle East." The World Economy 38, no. 11 (2015): 1650-1681.

Dennis, Nigel. "End of the free lunch? The responses of traditional European airlines to the lowcost carrier threat." Journal of Air Transport Management13, no. 5 (2007): 311-321.

Economist. "Israel's aviation deal with the EU" (March, 2014);

http://www.economist.com/blogs/gulliver/2014/03/israels-aviation-deal-eu

Egyptian Holding Company for Airports and Air Navigation. Statistics;

http://www.ehcaan.com/statistics.aspx

European Commission. "International Aviation: Israel";

http://ec.europa.eu/transport/modes/air/international_aviation/country_index/israel_en.htm

Flight Global. "Ryanair eyes Egypt and Tunisia routes in 2016”, flightglobal.com (May, 2015);

https://www.flightglobal.com/news/articles/ryanair-eyes-egypt-and-tunisia-routes-in-2016-411942/

Flight Global, Evolution of the African airline market (2013);

https://www.flightglobal.com/news/articles/analysis-evolution-of-the-african-airline-market-386448/

Hansman, R. John, and Mariya Ishutkina. "Analysis of the Interaction Between Air Transportation and Economic Activity: A Worldwide Perspective." ICAT-2009-2; (2009).

Haaretz. "Israel-EU Air Traffic Grows as Open Skies Spurs More Flights, Lower Fares", haaretz.com (February 2014);

http://www.haaretz.com/israel-news/business/.premium-1.640387

International Air Transport Association. Air Passenger Market Analysis (Jan-Dec, 2015); https://www.iata.org/publications/economics/Pages/Air-Passenger-Monthly-Analysis.aspx

InterVISTAS. "Transforming Intra-African Air Connectivity: The Economic Benefits of Implementing the Yamoussoukro Decision”. InterVISTAS Consulting Ltd, 2014. 
InterVISTAS. "The Impact of International Air Service Liberalization on Morocco". InterVISTAS Consulting Ltd, 2009.

Investing.com. "Air Arabia Financials";

http://ca.investing.com/equities/air-arabia-financial-summary

Itani, N., O'Connell, J.F., and K. Mason "Towards realizing best-in-class civil aviation strategy scenarios." Transport Policy, 43 (2015), 42-54

Maslen, Richard. "Air Transport Capacity in Middle East - A Market Snapshot", routesonline.com (2014);

http://www.routesonline.com/news/29/breaking-news/241942/air-transport-capacity-in-middle-east-a-marketsnapshot

Mason, Keith J., William G. Morrison and Iain Stockman. "Liberalisation of air transport in Europe and the evolution of 'low cost' airlines." in Hüschelrath, Kai, Hans-Martin Niemeier, Hartmut Wolf, David Gillen, and Peter Forsyth, eds. Liberalization in Aviation: Competition, Cooperation and Public Policy. Ashgate Publishing, Ltd. (2013): 141-157.

Mason, Keith J., and William G. Morrison. "Towards a means of consistently comparing airline business models with an application to the 'low cost'airline sector." Research in Transportation Economics 24, no. 1 (2008): 75-84.

Morrell, P., Airlines within airlines: An analysis of US network airline responses to Low Cost Carriers. Journal of Air Transport Management, 11, 303-312 (2005).

Morrison, W., and K.J. Mason, "So what is a low cost carrier? A product \& organisation architecture (POA) approach to defining airline business models", $10^{\text {th }}$ Air Transport Research Society Conference, Nagoya, Japan (May, 2006).

Njoya, Eric Tchouamou. "Africa's single aviation market: The progress so far." Journal of Transport Geography 50 (2016): 4-11.

Phelps, Glenn and Steve Cabtree. "Worldwide, Median Household Income About \$10,000, Gallup, 2013;

http://www.gallup.com/poll/166211/worldwide-median-household-income-000.aspx

Phocuswright; "Middle East Online Travel Overview, Second Edition”, 2015.

Routesonline. "Inside the Strategy Summit: Arab Liberalisation - Are the Skies Really Opening Up?", Routesonline.com, (May, 2015);

http://www.routesonline.com/news/29/breaking-news/249156/inside-the-strategy-summit-arab-liberalisation-are-theskies-really-opening-up/

Schlumberger, Charles E. “Open skies for Africa: implementing the Yamoussoukro decision”, World Bank Publications, 2010. 
Schlumberger, Charles E., and Nora Weisskopf. "Ready for Takeoff? : The Potential for Lowcost Carriers in Developing Countries". World Bank Publications, 2014.

Schlumberger, Charles and Nora Weisskopf. "Is the Arab Take-Off Imminent? Opportunities for the Development of the North African Air Transport Sector following the Arab Spring" Annals of Air and Space Law, V37, 2012.

Sosina, I. "Yammousoukro Decision and the Future of African Air Transport", Presentation: Air Services Negotiations Conference, Durban, 2013.

The Economist. "In it for the Long Haul”, economist.com (July, 2015);

http://www.economist.com/blogs/gulliver/2015/07/aviation-israel

The Economist. “Opening UP”, economist.com (March, 2014);

http://www.economist.com/blogs/gulliver/2014/03/israels-aviation-deal-eu

The National Business. "Air Arabia Jordan to commence flights in May from new Amman hub", thenational.ae (April 2015);

http://www.thenational.ae/business/aviation/air-arabia-jordan-to-commence-flights-in-may-from-new-amman-hub

Tong, Qingxia. "Wages Structure in the United Arab Emirates." Institute for Social and Economic Research, Zayed University. Working Paper 2 (2010).

Williams, G., Mason, K., \& Turner, S., 'Market analysis of Europe's low-cost airlines: An examination of trends in the economics and operating characteristics of Europe's charter and nofrills scheduled airlines.' Air Transport Group Research Report, Cranfield University (2003).

World Trade Organization. “Air Services Agreement Projector”, wto.org; https://www.wto.org/asap

World Travel and Tourism Council Data Gateway, 2016: http://www.wttc.org/datagateway/ 


\section{Appendix: LCC Business Strategy Benchmarking Indices ${ }^{39}$}

\begin{tabular}{|c|c|}
\hline Index Name & Index elements \\
\hline Cost drivers & Unit cost per ASK \\
\hline \multirow[t]{3}{*}{ Revenue drivers } & Yield per RPK \\
\hline & Operating revenue per sector \\
\hline & Average fare paid (incl. ancillary revenues) \\
\hline \multirow[t]{4}{*}{ Connectivity } & Network density - departures per airport per day \\
\hline & Routes offered \\
\hline & Average flight frequency \\
\hline & All destinations available at airports served \\
\hline \multirow[t]{5}{*}{ Convenience } & Average frequency per route \\
\hline & Airport location - average distance from nearest population centre \\
\hline & Flights at primary airports \\
\hline & Punctuality \\
\hline & Baggage service (customer rating) \\
\hline \multirow[t]{3}{*}{ Comfort } & Passengers per flight \\
\hline & Economy seat width \\
\hline & Economy seat pitch \\
\hline \multirow[t]{2}{*}{ Distribution/sales } & Ticketing, sales, promotion expense per passenger \\
\hline & Percentage of sales from internet bookings \\
\hline \multirow[t]{3}{*}{ Aircraft productivity } & Aircraft utilization (hours per day) \\
\hline & Uniformity of aircraft fleet \\
\hline & Aircraft sectors per day \\
\hline \multirow[t]{5}{*}{ Labour productivity } & Passengers per employee (adjusted by employee costs as a $\%$ of total cost) \\
\hline & Employees per aircraft \\
\hline & Personnel per ASK \\
\hline & Ratio of flight and cabin crew to total employees \\
\hline & ASK per employee \\
\hline \multirow[t]{4}{*}{ Airport attractiveness } & Percentage of city pair routes in which airline has a monopoly \\
\hline & Weighted average annual passengers at airports served \\
\hline & Number of full service airlines present at destinations \\
\hline & Airport/en route costs per passenger \\
\hline \multirow[t]{5}{*}{ Market structure } & Median Herfindahl index on seat capacity \\
\hline & Average Herfindahl index on seat capacity \\
\hline & Average number of competitors per route \\
\hline & Capacity share of seats \\
\hline & Average city size served \\
\hline
\end{tabular}

\footnotetext{
${ }^{39}$ Source: Mason and Morrison (2008)
} 
Table A1: Data used in the calculation of indices for easyJet, Ryanair and Air Arabia

\begin{tabular}{|c|c|c|c|c|}
\hline & $\begin{array}{c}\text { easyJet } \\
2014\end{array}$ & $\begin{array}{c}\text { Ryanair } \\
2014\end{array}$ & $\begin{array}{c}\text { Air Arabia } \\
2010\end{array}$ & $\begin{array}{c}\text { Air Arbia } \\
2014\end{array}$ \\
\hline Average Sector Distance (km) & 1,091 & 1,249 & 2,052 & 1,469 \\
\hline \multicolumn{5}{|l|}{ COMPETITIVE POSITION } \\
\hline \multicolumn{5}{|l|}{ Profitability } \\
\hline Profitability/Op ratio & $114.7 \%$ & $115.0 \%$ & $110.3 \%$ & $114.9 \%$ \\
\hline Load factor & $91.7 \%$ & $82.7 \%$ & $82.8 \%$ & $81.4 \%$ \\
\hline Margin between LF \& BELF & $11.8 \%$ & $10.8 \%$ & $7.7 \%$ & $10.5 \%$ \\
\hline Operating revenue per employee (GBP) & 469,168 & 436,233 & 261,822 & 364,376 \\
\hline \multicolumn{5}{|l|}{ Competitive Position } \\
\hline Median HHI on Capacity (Seat) & 2177 & 10000 & 10000 & 10000 \\
\hline Average $\mathrm{HHI}$ on Capacity (seat) & 4057 & 6419 & 9140 & 9044 \\
\hline Average No of competitors per route & 1.99 & 1.07 & 0.3 & 1.35 \\
\hline Percent of city pair routes are monopolies & $24.4 \%$ & $52.1 \%$ & $85.0 \%$ & $72.2 \%$ \\
\hline \multicolumn{5}{|l|}{ BENEFIT DRIVERS } \\
\hline \multicolumn{5}{|l|}{ Connectivity } \\
\hline Network density - Departures per airport p.d. & 8.9 & 7.7 & 1.9 & 2.0 \\
\hline Routes offered & 675 & 1600 & 46 & 79 \\
\hline Average frequency per route & 12.53 & 6.31 & 13.91 & 12.35 \\
\hline Routes per airport & 5.00 & 8.60 & 0.98 & 0.79 \\
\hline Average aircraft per airport & 1.67 & 1.60 & 0.53 & 0.39 \\
\hline \multicolumn{5}{|l|}{ Convenience } \\
\hline Punctuality & 87 & 91 & 90 & 85 \\
\hline Baggage Service (Skytrax rating) & 3 & 3 & 3 & 3 \\
\hline \multicolumn{5}{|l|}{ Comfort } \\
\hline Flight and cabin crew per aircraft & 33.9 & 28.6 & 31.4 & 33.0 \\
\hline Passengers per flight & 147.3 & 155.6 & 133.8 & 95.2 \\
\hline Passengers per flight and cabin crew members & 9,078 & 9,616 & 6,169 & 5,907 \\
\hline Economy Seat width & 17.5 & 17.2 & 17.5 & 17.5 \\
\hline Economy seat pitch & 29 & 30 & 31 & 31 \\
\hline Pax per Flight and Cabin Crew & 9,078 & 9,616 & 6169 & 5907 \\
\hline \multicolumn{5}{|l|}{ COST DRIVERS } \\
\hline \multicolumn{5}{|l|}{ Organisational design } \\
\hline Unit cost (per ASK) GBP pence & 4.96 & 2.81 & 3.01 & 3.15 \\
\hline Internet distribution (\%) & $90 \%$ & $99 \%$ & $60 \%$ & $60 \%$ \\
\hline Ticketing, Sales, Promotion per pax (GBP) & 1.59 & 1.90 & 1.37 & 0.00 \\
\hline Personnel cost as \% Op Cost & $12.1 \%$ & $10.6 \%$ & $13.9 \%$ & $14.2 \%$ \\
\hline \multicolumn{5}{|l|}{ Flight ops } \\
\hline Most populous aircraft type/mark accounts for fleet & $100.0 \%$ & $100.0 \%$ & $100.0 \%$ & $100.0 \%$ \\
\hline \multicolumn{5}{|l|}{ Fleet utlisation } \\
\hline Aircraft Utlilisation (aircraft hours per day) & 11.00 & 8.81 & 12.06 & 14.00 \\
\hline Aircraft sectors per day & 5.72 & 4.84 & 3.96 & 3.97 \\
\hline Average sector length $(\mathrm{km})$ & 1,091 & 1,249 & 2,052 & 1,469 \\
\hline airport/enroute costs per pax $(£)$ & 21.82 & 11.24 & 5.10 & 5.37 \\
\hline \multicolumn{5}{|l|}{ Employees } \\
\hline Pax per employee & 6,716 & 8,776 & 3,181 & 4,031 \\
\hline adjusted pax per employee & 815 & 929 & 441 & 571 \\
\hline Employees per aircraft & 43 & 31 & 56 & 43 \\
\hline Personnel cost per ASK & 0.60 & 0.30 & 0.42 & 0.45 \\
\hline Flight and cabin crew/total employees & $74.0 \%$ & $91.3 \%$ & $51.6 \%$ & $68.2 \%$ \\
\hline Labour cost as $\%$ of Total cost & $12.1 \%$ & $10.6 \%$ & $13.9 \%$ & $14.2 \%$ \\
\hline flight and Cabin crew/total emp & $74.0 \%$ & $91.3 \%$ & $51.6 \%$ & $68.2 \%$ \\
\hline ASK per employee ('000) & 8,242 & 13,475 & 7,897 & 10,072 \\
\hline Average wage (GBP) per emp & 49,642 & 40,153 & 32,883 & 44,927 \\
\hline \multicolumn{5}{|l|}{ Marketing and Pricing } \\
\hline Yield per RPK (GBP pence) & 6.21 & 3.91 & 4.00 & 4.44 \\
\hline Yiels per ASK (GBP Pence) & 5.69 & 3.24 & 3.32 & 3.62 \\
\hline Operating revenue per sector (GBP) & 10,290 & 7,736 & 11,014 & 8,608 \\
\hline Average fare paid (GBP) (incl ancillary rev) & 69.86 & 49.71 & 82.30 & 90.39 \\
\hline Ancillary revenue as $\%$ of operating revenue & $1.4 \%$ & $24.8 \%$ & $3.6 \%$ & $9.8 \%$ \\
\hline Ancillary revenue per passenger & $£ 1.00$ & $£ 12.31$ & $£ 2.94$ & $£ 8.82$ \\
\hline
\end{tabular}


2016-10-11

\section{Low cost carriers in the Middle East and North Africa: Prospects and strategies}

Morrison, W.G.

Elseveir

Morrison WG, Mason K, Low cost carriers in the Middle East and North Africa: Prospects and strategies, Research in Transportation Business and Management, Volume 21, Issue December, 2016, pp. 54-67

http://dx.doi.org/10.1016/j.rtbm.2016.09.005

Downloaded from Cranfield Library Services E-Repository 